
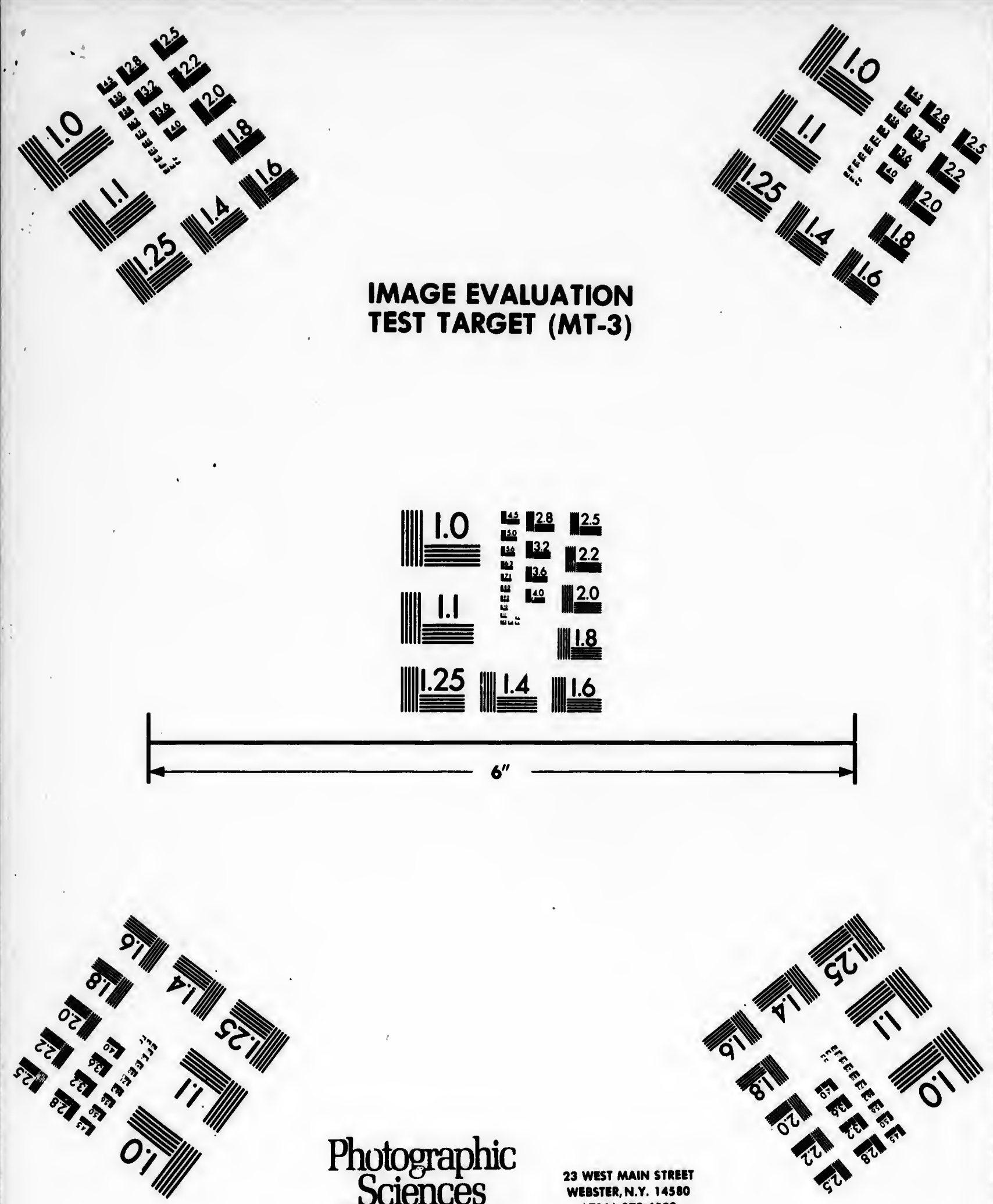

Photographic Sciences Corporation

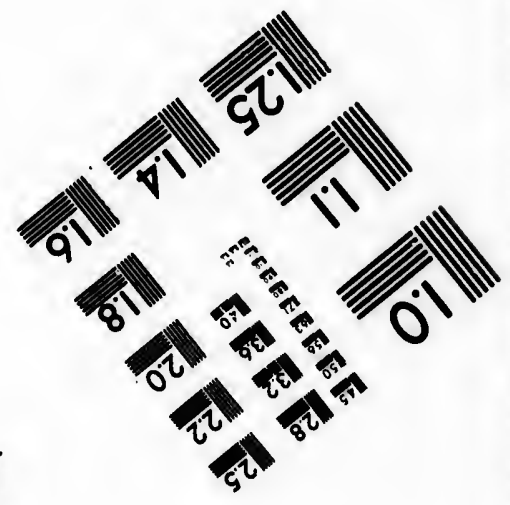


0

CIHM/ICMH Microfiche Series.

\section{CIHM/ICMH Collection de microfiches.}

Canadian Institute for Historical Microreproductions / Inatitut canadien de microreproductions historiques
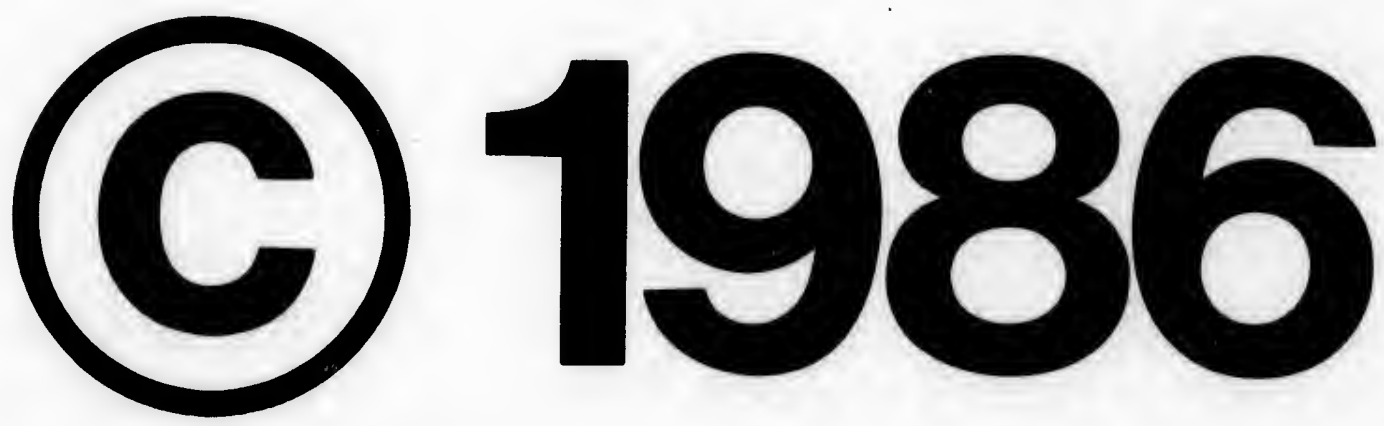
The Institute has attempted to obtain the beat original copy available for filming. Fatures of this copy which may be blbliographically unique. which may alter any of the images in the reproduction, or which may significantly change the usual method of filming, are checked below.

\section{Coloured covars/}

Couverture de coulour

\section{Covers damaged/ \\ Couvertura endommagie}

Covers restored and/or laminated/

Couverture reatourde et/ou pelliculice.

Cover title missing/

Le titre de couverture manque

Colourad mapa/

Cartes getographiques on couleur

Coloured ink (i.e. other than blue or black)/

Encre de couleur (i.e. autre que bleve ou noirel

Coloured plates and/or illustrationa/

Planchea ex/ou llluatrationa en couleur

Bound with other material/

Relic ovec d'autres documents

Tight binding may cause shadows or distortion along interior mergin/

La re liure serrée paut causer de l'ombre ou de la distorsion le long de la marge intórieure

Blank leaves added during restoration may appear within the text. Whenover possible, these have been omitted from filming/

II se peut que certaines pages blanches ajoutces lors d'une restauration apparaisaent dana le texte. mais, lorsque cele dtait possible, ces pagea n'ont pas eté filmbes.

Additional comments:/

Commentaires supplómentaires:
L'Institut a microfilmb le meille ve exemplaire qu'il lui a été possibile da sa procurer. Les détails de cet exemplaire qul sont peut-btre uniques du point da vue bibliographiqua, qui peuvent modifier une image reproduite, ou qui peuvent exiger une modification dans la mothode normale de filmage sont indiqubs ci-dessous.

\section{Coloured pagea/}

Pages de coulour

Pages dameged/

Pages endommagies

Pages restored and/or lamineted/

Pages restaurces ot/ou pelliculés

Pages discoloured, stained or foxed/

Pages décolortes, tachetces ou piquees

Pages detached/

Pages dótachios

Showthrough/

Transparence

Quality of print varies/

Qualite intgale de l'impression

Includes supplementary material/

Comprend du matóriel supplémentaire

Oniy edition available/

Seule edition disponible

Pages wholly or partially obscured by errata slips, tissues, otc., have been refilmed to ensure the best possible image/

Les peges totalement ou partiellement obscurcies par un feuillet d'errata, une pelure. etc.. ont bté filmés nouveau de facon a obtenir la meilleure image possible.

This item is filmed at the reduction ratio checked below/ Ce document est filmo au taux de réduction indique ci-dessous.

$10 x$ $14 x$ $18 x$

$22 x$

$26 x$

$30 x$

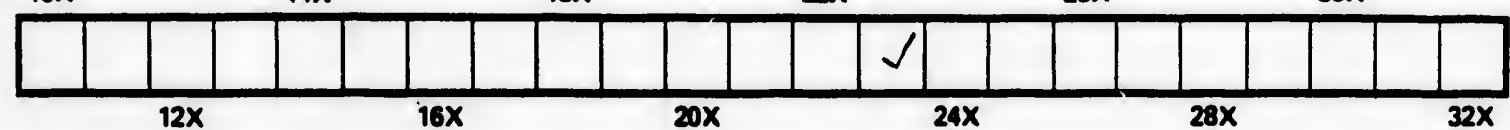

The

aho

TIN whi

\section{Mar}

diff

enti

beg

righ

requ mot 
The copy fllmed here has beien reproduced thanke to the generoslty of:

\section{Library of the Public}

Archives of Canada

The imeges appearing here are the beat quality posslble concidering the condition and loglbility of the orlginal copy and in keoping with the filming contract specifications.

Original coples in printed paper covers are filmod beginning with the front covor and ending on the last page with a printed or Illustrated Impres. slon, or the back cover when appropriate. All other original coples are filmed beginning on the first page with a printed or illustrated impresalon, and ending on the last page with a printed or Illustroted impresilon.

The last recorded frame on each microfiche shall contein the oymbol $\rightarrow$ imeaning "CONTINUED"), or the symbol $\nabla$ (meaning "END"). whichover eppiles.

Mape, plates, charts, etc., may be filmed et different reduction ratios. Those too large to be entirely included in one exposure are filmed beginning in the upper loft hand corner, loft to right and top to bottom, es many frames as required. The following diegrems illustrate the mothod:
L'oxemplaire fllmo fut reprodult arice a lo góncroeltó do:

La blbliothdque des Archives publiques du Canada

Les images sulvantes ont ste reprodultes avec le plus grand soln, compte tonu de le condition et do la nottoté do l'oxomplaire flims, ot en conformits avec les conditions du contrat do fllmage.

Les exemplaires orlginaux dont le couverture en papler est imprimbe sont fllimbe en commençant par lo promior plat ot on terminant solt par la dernlore page qui comporte une emprolnte d'Impression ou d'illustration, solt par lo second plat, solon lo cas. Tous les autres exemplaires originaux sont filmbe en commençant par la promilore page qul comporte une emprointe d'imprescion ou d'illustration ot en torminant par la dernilore page qul comporte une telle empreinte.

Un des symboles sulvants apparaitra sur la dernidure image de chaque microfiche, selon le ces: lo symbole $\rightarrow$ signifio "A SUIVRE", is symbole $\nabla$ signifie "FIN".

Les cartes, planches, tableaux, etc., peuvent etre flimbs des taux de róduction diffórents. Loreque le document est trop grand pour stre reproduit on un seul clichs, II est fllmo a portir de l'angle supérieur gauche, de gauche de droite, ot de haut on bas. en prenant lo nombre d'images nócessaire. Les diagrammes sulvants Illuetrent la móthode.
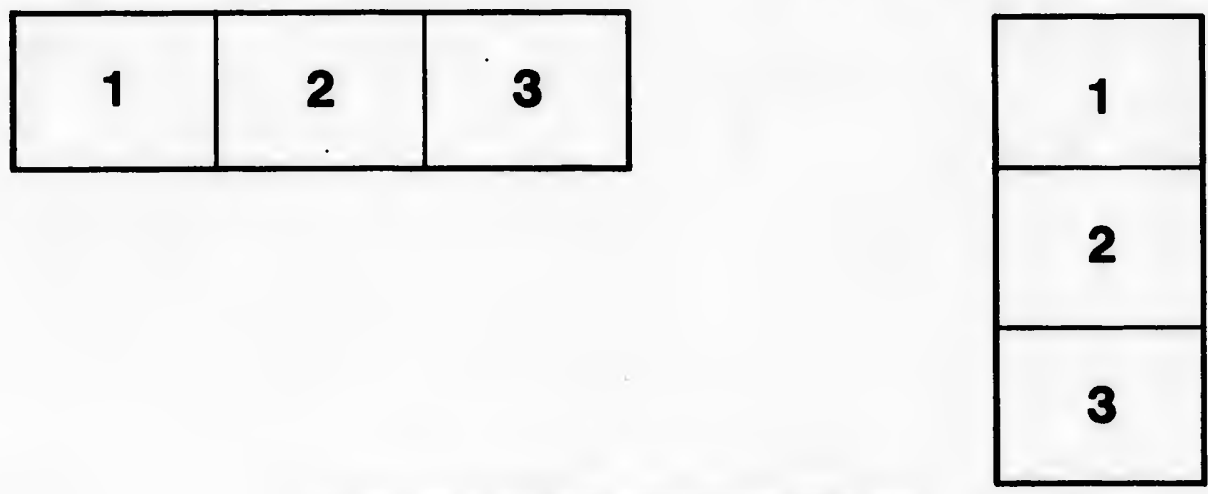

\begin{tabular}{|l|l|l|}
\hline 1 & 2 & 3 \\
\hline 4 & 5 & 6 \\
\hline
\end{tabular}




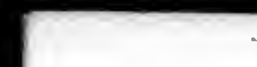


32.254

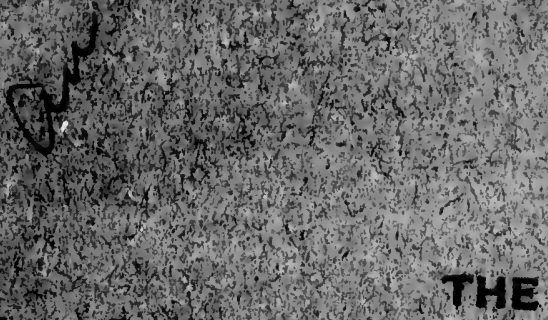

\section{Segrophical Distribution}

\section{of Torest Trees in}

\section{Canada}

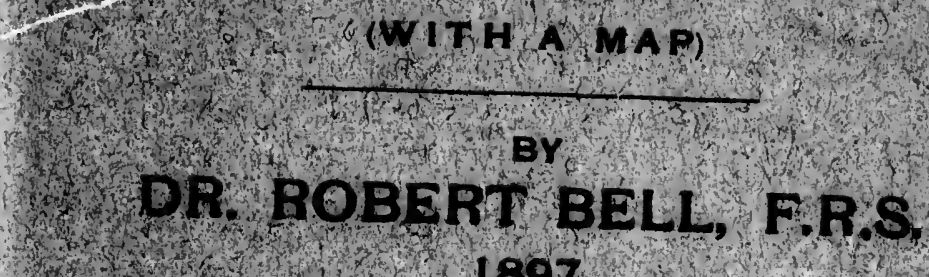

\section{7}

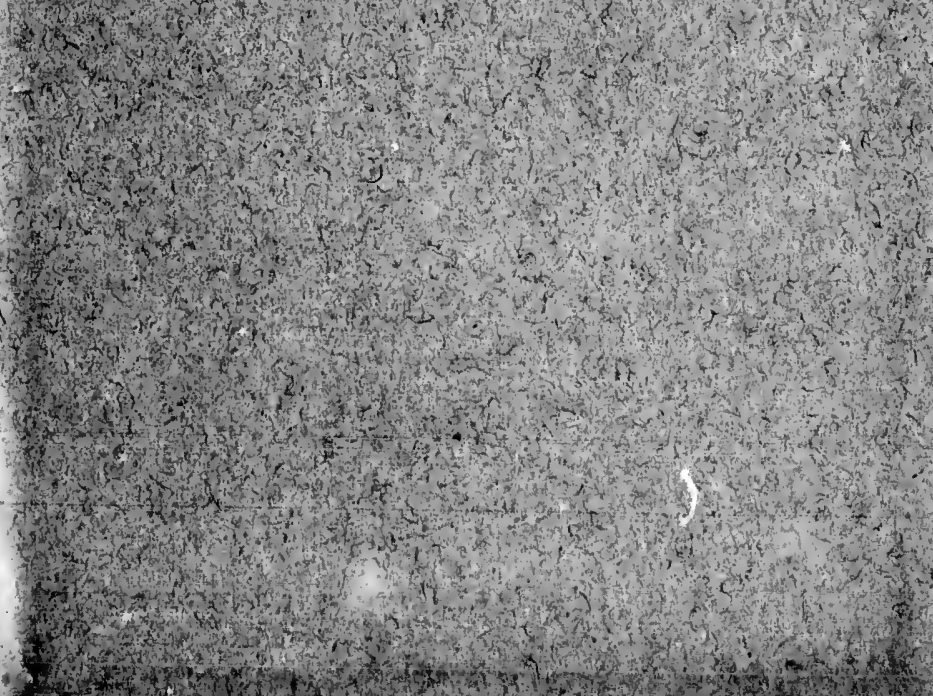




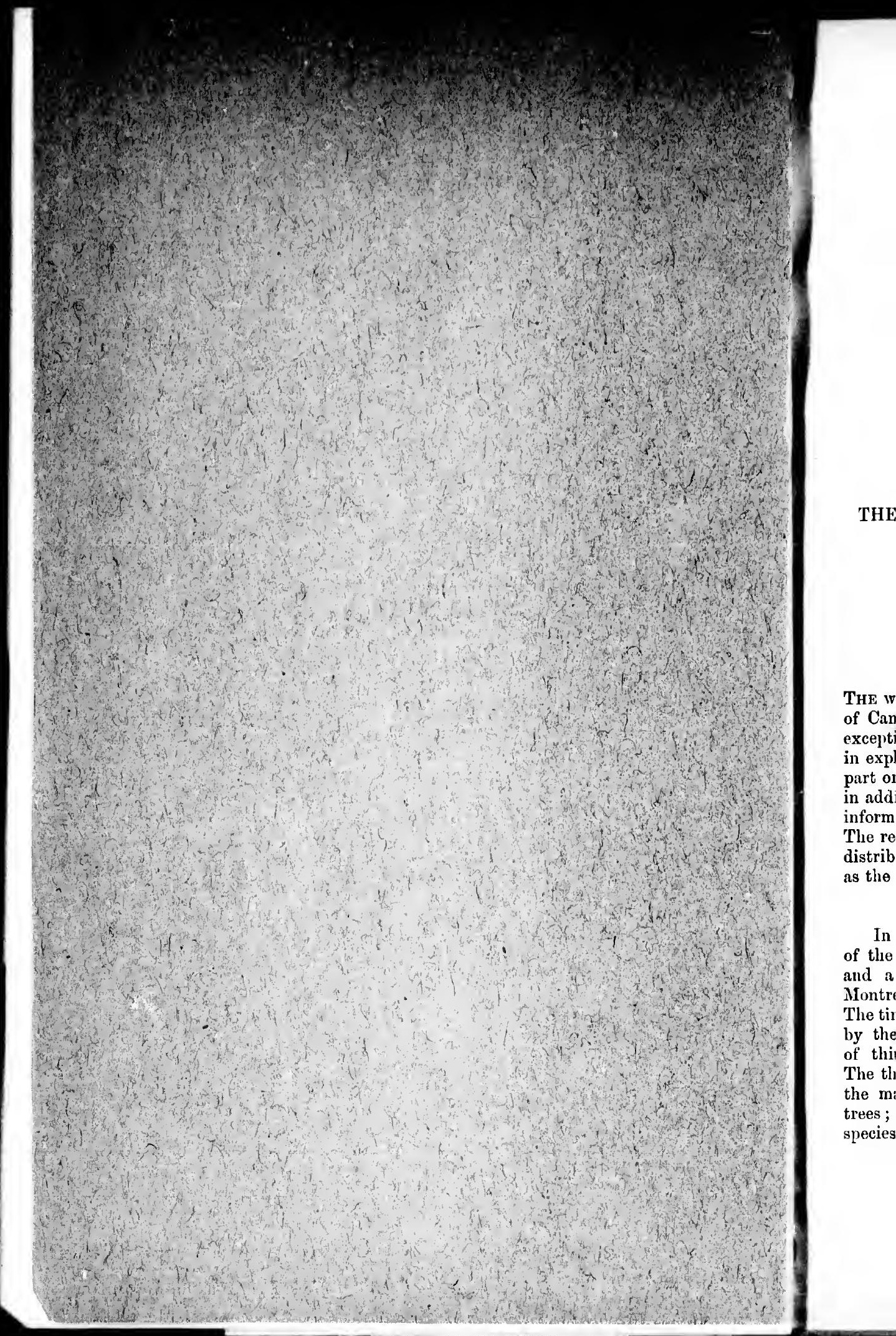


Reprintel from The Scottish Gengraphical Magazine for June 1807.

\title{
THE GEOGRAPHICAL DISTRIBUTION OF FOREST TREES IN CANADA.
}

\author{
By Dr. Robert Bell.
}

(Read before the Society at Edinburgh and Glasgow, in March.)

(With a Map.)

\section{INTRODUCTION.}

THE writer has studied the geographical distribution of the forest trees of Canada for the last forty years, and during all that time he has had exceptional opportunities for observation, having been engaged each year in exploring, in connection with the Government Geological Survey, one part or another of the region represented on the accompanying map; and, in addition to this extensive personal observation, he has collected much information on the subject from a great number of other travellers. The result has been to ascertain, with considerable accuracy, the limits of distribution of all our native trees from the Atlantic Ocean as far west as the prairie regions.

\section{Tree-Line Map.}

In 1873 he prepared a large map showing the nortliern limits of the principal trees in the four original provinces of the Dominion, and a reduction of this sheet was published in the report of the Montreal Horticultural Society and Fruit Growers' Association for 1879. The timber-tree map accompanying his official report for 1880 , published by the Geological Survey in 1882, gives the general northern limits of thirty of our principal forest trees east of the Rocky mountains. The thirty species whose bonndaries are shown with greater accuracy on the map accompanying the present paper embrace most of the same trees; but a few substitutions have been made in order to introduce other species of more general interest without increasing the total number 
represented, which is as large as can be exhibited with clearness on the scale of 80 miles to 1 inch.

The same sigus or forms of conventional lines have been retained for the several species in all the maps, and they have also been adopted where similar work has been done in adjacent parts of the United States. Our present map covers the most important and interesting portion of the great forest region of Canada. Beyond this area the northern species extend to Alaska, and there are valuable forests west of the prairies, in the Rocky mountains and British Columbia. But the northern group embraces only nine species, and the contours of their limits are not knuwn to possess any peculiarities which cannot be described without a map. On the plains, trees of any kind oceur only in favoured situations, and the different species are seattered in such a way that it would be difficult to represent the boundaries of their distribution on a map, while in British Columbia most of the trees are of different species from those east of the Rocky mountains, and they would require to be shown on a separate sheet.

\section{IN IAABRADOR.}

The nap of the Labrador peninsula, published in the Scottish Geographical Magazine for July 1895, gives the limits of each of the forest trees in that region so far as they are known up to the present time; but owing to the comparatively small amount of exploration which has yet been done in that peninsula, these tree-lines cannot be expected to be so aceurate in detail as those of the rest of our map. The official reports of explorations made for the Geological Survey by the writer have generally contained notes on the forest trees of each region, and these have been utilised in preparing the present map. The writer is also indebted for various facts to nearly all his colleagues on the Geological Survey who are engaged in exploring work, and more especially to Messrs. Tyrrell, Low, and Macoun.

\section{Forest Wealtil of Nortil America.}

North Ameriea possesses a forest wcalth which is perhaps unequalled in any other region on the globe. No fewer than 340 species of trees are known to be indigenous to the United States. Of these, 123 grow in Canada, 94 occurring east of the Rocky mountains, and the remaining 29 on the Pacific slope. Sixty-four of those east of the mountains are therefore unrepresented on the map, but the greater number of them are confined to small areas in southern Ontario, while those which extend beyond this district are apparently of less interest with regard to their distribution than the thirty species which have been selected for presentation.

\section{Accuricy of the Tree-Lines.}

The contours of the limiting lines of each species have been carefully laid down from every souree of information up to the present ycar, and, except in the Labrador peninsula, they cannot be far from the truth. If

there

coloni the for specie! exist $t$ not al we sel specim

In to be nearly suppos nearly diverg that $t 1$ entire whose and ta

In forest trodue purpo:

In called as to middl splend settlen nessec farm of na povert only a ring 
arness on the

retained for been adopted United States. hg portion of thern species e prairies, in rthern group mits are not ed without a ed situations, it would 'be a map, while es from those e shown on a

Scottish Geoof the forest oresent time; on which has xpected to be fficial reports writer have on, and these vriter is also he Geological dly to Messrs.

ps unequalled ecies of trees se, 123 grow he remaining aountains are r of them are e which exith regard to selected for

cen carefully nt year, and, he truth. If there be any defect, it may be the omission of small outliers, patches, or colonies beyond the general boundary of a species, or of small inliers in the form of blank spaces within such boundary in which no trees of the species may occur; but it is probable that if areas such as the former do exist they are of no great extent, while the occurrence of the latter will not alter the general boundaries. As a rule, we may assume that if we select any particular spot on the map we shall find near at hand specimens of all the trees whose limits lie to the northward of it.

\section{Fonser Erroneous Conceptions.}

In the southern portions of Quebec and Ontario, which were the first to be colonised by Europeans, it was observed that the tree-lines ran nearly east and west, and, before the subject had been investigated, it was supposed that the northern limits of the trees of Canada in general ran nearly in this direction; but, as tho present map shows, there are great divergencies in the contours of the limit-lines of many species, proving that these contours are governed by other causes than mere latitude.

Only one out of the 340 species of trees above referred to is almost entirely confined to Canada, namely, the widely dispersed Banksian pine, whose southern boundary only touches the south shore of Lake Superior and takes in a small part of the State of Minnesota.

\section{Canadi as a Whole.}

In the descriptions to follow, the geographical distribution of our forest trees is treated without reference to provincial boundaries, the introduction of which would only complicate matters and serve no good purpose.

\section{Recion of Luxuriant Mixed Forest.}

In Canada and the United States the forests are more commonly called "woods" and "bush." The finest forests of North America, both as to variety of species and lnxuriance of growth, were those of the middle and northern stat $:=$, of which Ohio is about the centre. These splendid woorls, which have Sen largely destroyed in the progress of the settlement of the country, extend into Pennsylvania, Kentucky, Tennessce, Indiana, Michigan, and southern Ontario. On any uncleared farm lot in the last-named region, one might find fifty or more kinds of native trees, all mingled together. This is in marked contrast to the poverty in species of the indigenous forests of the British Islands, where only abont a dozen are represented, or indeed to the small number occurring in the forests of Europe in general.

\section{Botanic Linits of Treess.}

The tree-lines on the map represent the limits of each species from a botanic rather than an economic point of view; for in some parts of its range the trees of any species may be so small or scattered as to have no commercial value. But as the public know so little as yet about such 
matters, these lines may be of considerable importance in connection with questions affecting the future supplies of our various kinds of timber. Not so many years ago a vague impression prevailed in Canada that there was scarcely any limit to the northward and westward range of the white pine, which afforded our staple export timber. The author's trce-map, published in 1879 , first dispelled this illusion, and caused some alarm among those interested in our forest wealth. One of the causes of this erroneous impression was the frequent allusions by travellers and the Hudson Bay Company's men, who came from Britain, to "pine" in the northern regions. To Canadians the word "pine," without any qualification, always means the white pine (Pinus strobus), and it appears to have been taken for grantod that the persons just referred to used it in the same sense, whereas they referred to the spruce or balsam fir.

\section{Gradual and abrupt Termination of Trees.}

In approaching their northern limits, some kinds of trees become uradually smaller and smaller, and are finally reduced to mere bushes before they disappear altogether, while others terminate abruptly or without any apparent diminution in the average size of the individual trunks. The latter habit is commoner in the southern than in the northern species, and it appears to prevail more in the eastern than in the western parts of Canada. As examples of this we may cite the black walnut, the chestnut, buttonwood, elm, yellow birch, basswood, hemlock, white and red pine, and white cedar.

It is probable that those trees which bear large numbers of seeds, capable of being carried for some distance by the wind, such as the conifers and the poplars, have now reached the extreme northern limits of their growth; but some other species may be continuing to extend their borders. Indeed the general tendency appears to be to advance still farther north, as if many kinds of our trees had not yet had sufficient time to occupy all the territory congenial to their existence. In support of this view it may be mentioned that the few experiments that have been made in artificially transferring the more southern species northward have been successful through long distances. Among these experiments one of the most important is that of the Hon. Sir Henri Joly de Lotbinière, who has found that the black walnut grows well and forms wood rapidly near the city of Quebec, although the nearest place in Canada where it is found growing naturally is in the Niagara district, about 500 miles to the south-west. At Carleton Place, thirty-five miles south-west of Ottawa City, and 200 miles from the Niagara district, the late Mr. Robert Bell raised black walnut-trces, which are now producing ripe nuts. These facts prove that the range of this, our most valuable timber, is capable of being extended over a much greater area than it yet occupies naturally. Pelee Island, in Lake Erie, is the most southern portion of Canada, and this is the only locality in the country where the honey-locust and the Kentucky coffeetree are known to grow naturally; but the former flourishes well

and

The

a dor

black

bear

it ocs

this

a sho

to th

on $t$

then

Hud

circl

apps

coas

stud

way

and 
n connection ous kinds of od in Canada tward range The author's and caused One of the allusions by came from as the word pine (Pinus the persons referred to

ss.

rees become mere bushes abruptly or $\theta$ individual than in the tern than in nay cite the h, basswood,

ers of seeds, such as the rthern limits intinuing to ars to be to ees had not nial to their hat the fow ig the more og distances. of the Hon. lack walnut ec, although ally is in the rleton Place, es from the walnut-trees, $t$ the range tended over e Island, in is the only ucky coffeeurishes well wherever it has been planted, throughout the lake peninsula of Ontario, and down the St. Lawrence nearly to Montreal, and small trees of it are also doing well at Ottawa. The Kentucky coffee-tree has also been found to grow to maturity at Ottawa. The negundo, or Manitoba maple, has not extended its range east of the western part of Lake Superior, and yet it is found to grow as well all the way to Montreal, 900 miles to the east of this, as it does in Manitoba. It is also successfully cultivated at Lac la Biche, far to the north-west of its natural habitat. The black ash proves quite hardy when transported to Moose Factory on James Bay, more than 100 miles northward of its present range, and where it is exposed to the chilling influence of the sea air. There is little doubt that other kinds of trees, if tried, would be found to flourish beyond their present range. This ability of various native trees to grow far from thoir existing limits is probably not attributable to an improvement in the climate since they attained their present range, for there is no meteorological proof of such improvement, and, on the contrary, there is evidence that the verge of the forest is retreating southward both in North America and Asia. It is more likely due to the callse above suggested, namoly, that sufficient time has not yet elapsed to have permitted the fullest possible territorial expansion of all the species.

When frost alone operates to check the northward extension of a tree, there would appear to be no reason why such a species should not grow as far in that direction as it can ripen its sceds, even once in a number of years. When early frost happened to coincide with good seed years, many seasons might intervene between crops of ripo seeds, and the natural progress of northward extension would be very slow. The red oak, which requires two seasons to ripen its fruit, would suffer a double disadvantage. The writer has noticed that beech, elm, and black asls-trees, when growing in the most northern situations, seldom bear any fruit.

As a rule, ench species is at its best in the central part of the area it occupies, both as to breadth and longitudinal extension. Following this rule in cases where the northern limits of certain species only come a short distance into Canada, the finest specimens of these will be found to the southward, in the United States.

\section{Some Features of the Tree-Linfs.}

One of the most striking characteristics of the tree-limits, as shown on the accompanying map, is the approximate parallelism of many of them to the general trend of the various sea-coasts, including those of Hudson Bay: There is, therefore, obviously some connection of the one circumstance with the other, and this connection becomes still more apparent when we also take into consideration the lines of former seacoasts which must have existed when the land was at lower levels. A study of certain tree-lines shows that their present contours are in some way connected with conditions which existed in late geological times, and that any explanation of them must be involved with questions of 
l'leistocene geology, such as the elovation and partial subsidence of the continent, with consequent changes in the ocean currents and in the temperatures of both sea and land; also with the shifting of glacial centres, followed by the presence or absence of ice in certicin regions at different times. The distribution of the Banksian pine and the balsam poplar will serve to illustrate the above inference. The former soems to shun proximity to the sea, while the latter seeks it. If we trace the boundary of the Banksian pine throughout its whole course, we shall observe that it nowhere touches the salt water, while the balsam poplar is found everywhere near to the sea ns far north as it can grow, but it is npparently wanting over a great area in the central part of Labrador, which is probably too far inland for it to flourish. The sonthern lobe of this vacant space extends into the Ottawa valley in precisely the same south-westerly direction that was followed by the land ice from the old centro of glaciation in central Labrador to this valley. The erratic course of the balsam poplar line north-west of Hudson Bay may be connected with changes which took place in the later movements of the glacier ice in that region.

\section{Continuation of Plistocene Conditions.}

Around tho shores of James Bily the land is only moderately elevated for a considerable distance inland, especinlly on the west sile, whero a level tract extends for more than 100 miles from the sea. This border of low land affords abundant evidence of having been submerged in postPliocene times, and the line of the lanksian pine still skirts its margin all the way round, not lanving had time as yet to invade the old seabottom to any appreciable extent. It will be observed that the southern boundary of the Banksian pine reaches its extreme limit between the lower part of the Ottawa river and Georgin Bay of Lake Huron, where it intersects the 45 th parallel. In explanation of this decided southward curve, we find unusually high ground to the north-west of Ottawa and throughout much of the trinct between this city and Georgian Bay, which would stand out as a promontory when the sea covered the country to the south and east, as it is known to have done at about the same time as it submerged the district around the head of James Bay. $\Lambda \mathrm{n}$ outlier of the Banksian pine occurs in New Brunswick, and another in Nova Scotia, both being at some distance from the open sea.

\section{Peculiarities of the Winte Cenar Line.}

The boundary of the white cedar is perbaps the most remarkable treeline upon the map. In the central part its course is tolerably direct, but in both the east and west it turns southward and crosses the other treelines at right angles. If it had followed the average course of the boundaries of the other trees with which it is associated, it would have included the island of Anticosti, the whole of the maritime provinces, and the grenter part of Newfoundland, in all of which the conditions of climate, soil, etc., are evidently as favourable for the growth of this tree as they are in New Brunswick and the Gaspé peninsula, where it is quite

would no see region not $r e$ and $\mathrm{s}$ ? possib logged capab of sea little pagati attrac to she cedar

Lawr have New

those

diffiet

whicl tion, the $v$ eastel wouls trees 
dence of the and in the $g$ of glacial in regions at the balsam ormer scems If we trace rse, we shall alsam poplar grow, but it of Labrador, outhern lobe ly the same rom the old The erratic may be conpents of the

ely elevated de, where a This border ged in postits margin he old seahe southern etween the uron, where I soutli ward Jtawa and Bay, which country to ce time as it outlier of ova Scotia,

kable treedirect, but ther treese of the ould have provinces, ditions of this tree $t$ is quite abundant, and even larger and finer than usual. The most probable explanation of this singular feature is to suppose that when the tree had established itself in the latter regions, Nova Scotia was an island, and that the seeds of the cedar had no good means of crossing a considerable breadth of wator. There is evidence that a strait did separate Nova Scotia from New Brunswick where the cedar line passes, but since it became dry land the tree has made little progress towards occupying the peninsula. The white cedar occurs in the westem part of Prince Fdward Islaud, and in the form of a few clumps on the eastern side of the Bay of Fundy.

If these occurrences are due to secds lanving floated thither, this fact would show that they are not killed by immersion in salt water, and that no seeds have yot floated to the more distant shores of the cedarless regions above mentioned, or that, if some have chanced to do so, they did not reach suitable ground in which to grow. The cones of the cedar open and shed their seeds before they themselves fall off the trees, and it is possible that the naked seeds, on being blown into tho sea, become waterlogged and sink. It could then only be by a rare accident that seeds capable of germinating would be carried ncross any considerable breadth of sea water. When stranded upon a distant beach, they would have little clance of being carried from it to a suitable soil for their pro. pagation, as, owing to their unpleasant taste and odour, they have no attraction for any bird or beast. These suggestions are made in order to show that there may be some simple reason for the absence of the cedar from the greater part of the lands surrounding the Gulf of St. Lawrence. Tho clurents in the Gulf, and the strong tide which must have passed through the strait formerly separating Nova Scotia from New Brunswick, may have prevented the seeds of the cedar crossing to those parts from which the tree is absent; but if this were so, it becomes difficult to understand why the white pine, yellow birch, and other trees which are more sonthern in their general habit than the species in question, should be found in the cedariess areas. If some one were to plant the white cedar in Anticosti, Newfoundland, Cape Breton, and the eastern parts of Nova Scotia and Prince Edward Island, the experiment would be of much interest; and the writer ventures to predict that the trees would do well.

To the west of James Bay the white cedar attains a higher latitude than anywhere else, owing probably to the occurrence there of limestone rocks which afford suitable conditions for its growth. From this latitude it drops suddenly to the south of English river, and then turns westward to the head of Lake Winnipeg-in both cases running directly across the other tree-lines-and from the latter point it continues south into the United States, keeping on the east side of the Red river valley. The pronounced bend to the south side of English river may have some significance in connection with the last phase of glacial action in this region.

A remarkable ontlier of small white cedars occurs around Cedar lake on the Saskatchewan river near its mouth, and at a distance of nearly 290 miles north ward from the nearest point on the main boundary of the 
species at the south end of Lake Winnipeg. The existence of the white cedar at this particular locality, so far removed from its general limits, may have been rendered possible by a combination of conditions such as the required soil, moisture, warmth, etc., which may not be all united at any intermediate locality; or perhaps some better explanation may be found to account for this singular outlier.

Perhaps it is due to human agency, as the Indians often carry cedar boughs in the bottoms of their canoes as a lining, for which purpose they are very suitable on account of their flatness. It is probable that if care were taken to plant the cedar in suitable situations, it would be found to grow at almost any other locality on the western side of Lake Winnipeg, for it appears probable that this and some other species of our trees have not yet reached in all quarters the limits of their possible extension from the southward; in other words, it is not by any means certain that the present limits of all our trees have become permanently established. Some of them may be still slowly progressing from the southward in one part, and possibly retreating in another, or some may be advancing or retiring all along the line.

The slow rate at which most kinds of trees have spread themselves over the country is evidence, either that more than 19,000 or 20,000 years have elapsed since the glaciers retired from their most southern extension to the Arctic regions, or that they were never confluent across the greater part of the intervening country.

\section{Means for the Diffusion of Trees.}

The seeds of some kinds of trees are endowed with much better means of transportation than others, as, for example, the down of the poplar seeds and the wings of those of the conifers, and hence such species may have reached the utmost limits of their possible growth. Some species are prolific in individual trees, while others are nowhere common, being only sparingly scattered in all parts of their area of distribution, and as they produce proportionately less seed, they will make slower progress in occupying new ground. With some species "seed years" occur seldomer than with others, and this is another cause of disparity in the rate of dispersion of different species. The number of seeds produced by some of the nut-bearing trees is extremely small compared with that of most others, and no provision is made for scattering the nuts by the wind. But other means are not wanting, and one of the most interesting is that of the squirrels and the birds of prey. It is a common thing for a squirrel, when running off with a nut to a distance from the parent iree, to be attacked by a hawk, when he will immediately drop his burden to facilitate his escape, and this nut may have an opportunity to germinate the following spring. Again, if he should fall a prey to the bird, all the "caches" of nuts which he has made in the ground may grow the next year.

\section{Outuiers or Colonies.}

The following may be mentioned as examples of the known outliers or 
of the white neral limits, tions such as all united at tion may be carry cedar purpose they that if care be found to e Winnipeg, of our trees ble extension certain that established. ward in one dvancing or

themselves o or 20,000 bst southern fluent across

jettsr means the poplar such species wth. Some re common, listribution, aake slower seed years" ise of disnumber of small comattering the of the most - It is a a distance mmediately y have an should fall sade in the

outliers or

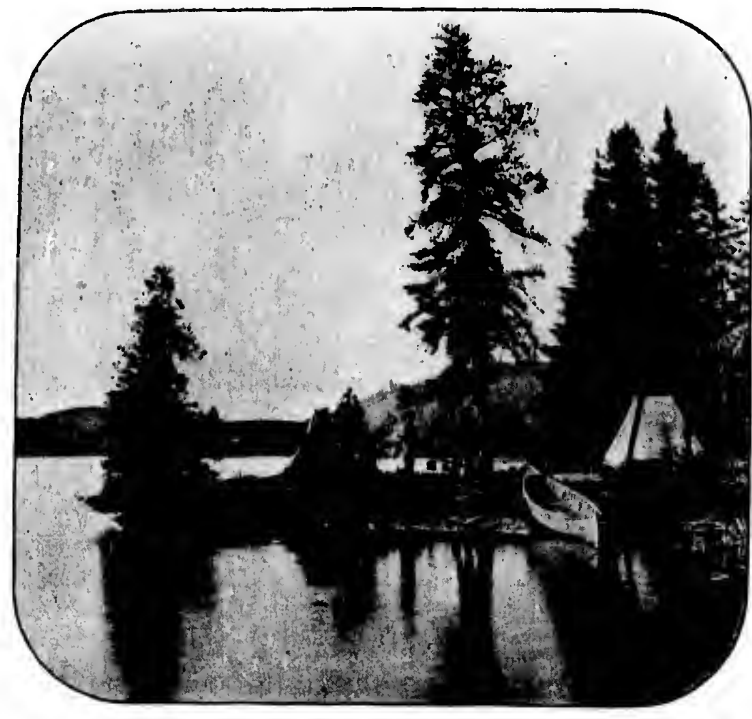

BANKSIAN PINE (Pinus Banksiant ).

(N,B,-The centrul tree only.)

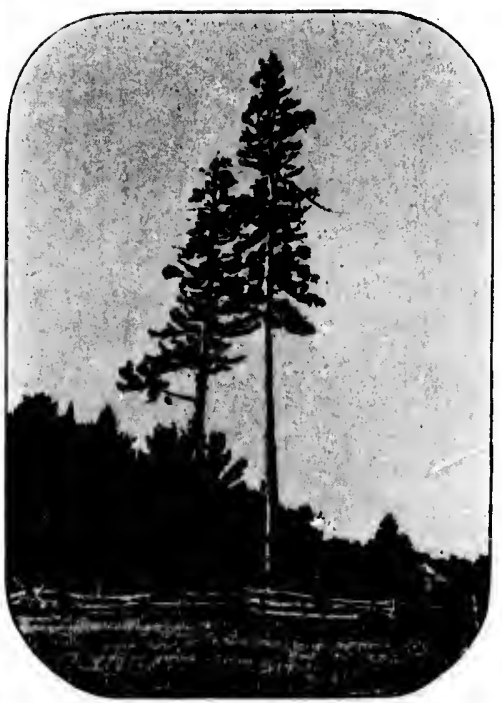

WIITE PINE (Pinus strobus)

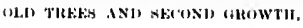

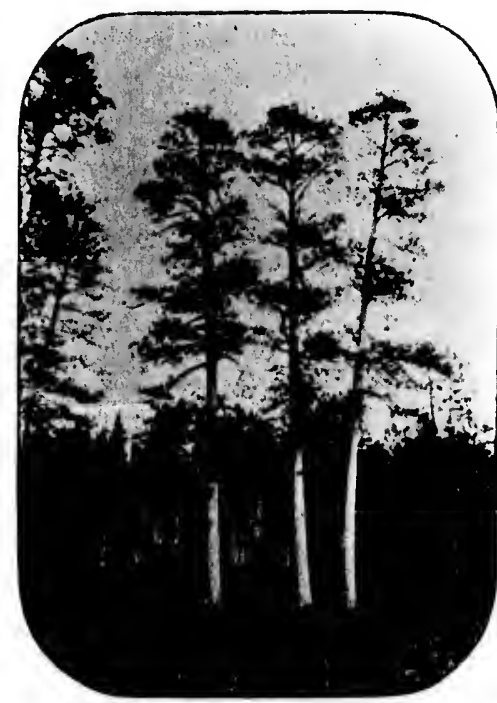

RED PINE.

(Jintes resinost.) 

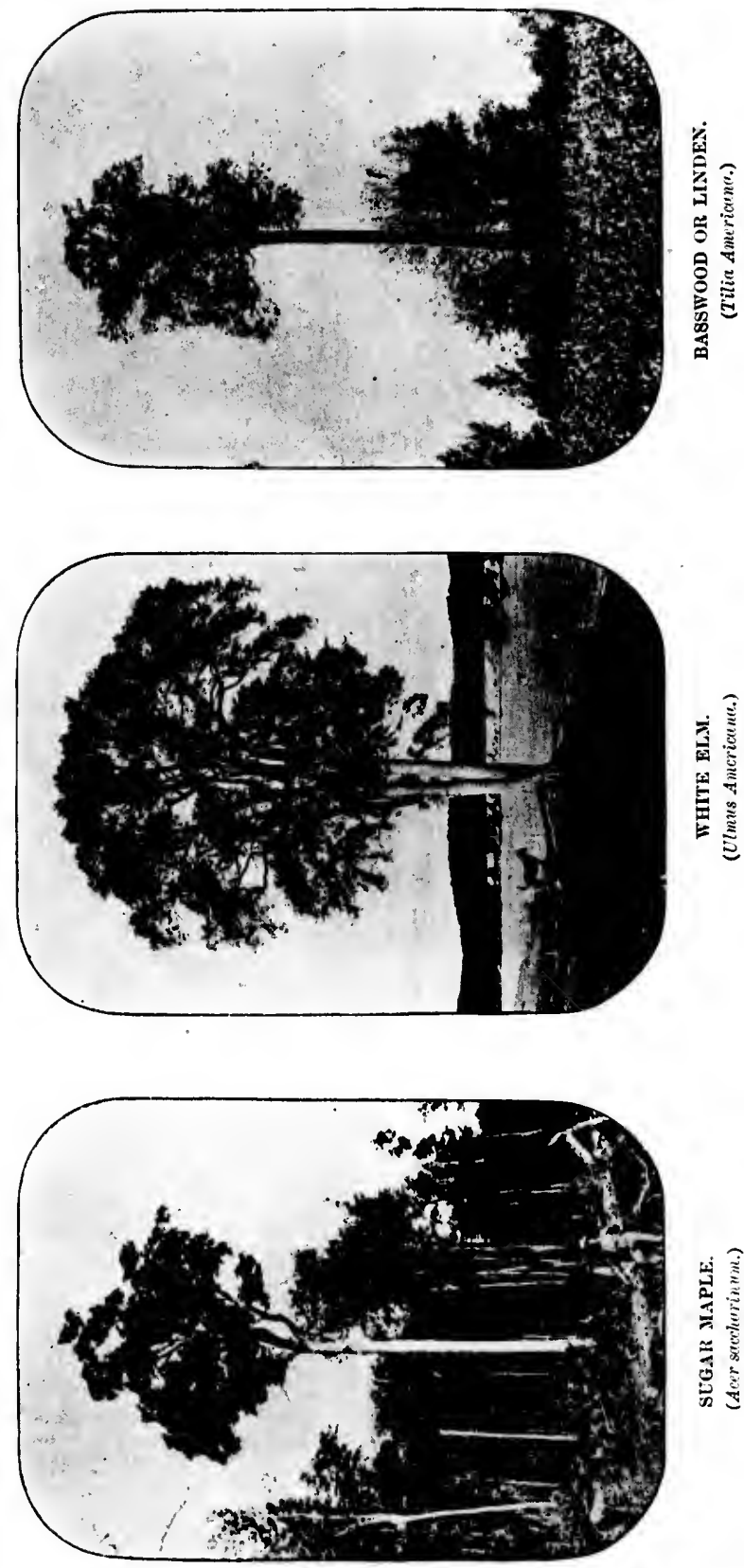

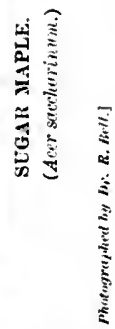

colonies

various $\mathrm{s}$

1. $I$

Brunswi

2. $I$

this tree

Superior.

3. $I$

covered

Abittibi

included

mentions

of the $\mathbf{C}$

grove of

4. $I$

and on $t$

to, as $w$

Saskatch

occur in

the shor

escape of

5. $H$

Minneso

the tree

supposed

6. $B$

of the $\mathrm{B}$

7. $B_{1}$

of Quebe species.

8. $B$ north of outside river of nor in th by Dr. $S$

9. $I$ ago alor main bo

The theory $t$ on accor garded : species,

Blan which $\mathrm{n}$ 
colonies of trees ontirely separated from the main areas occupied by the various species:-

\section{Brunswick.}

1. Banksian Pine.-One in Nova Scotia, and another in New

2. White Pine--Several isolated patches near the northern limit of this tree beyond the Upper Ottawa river, and others north of Lake Superior.

3. Red Pine, - One on Big Black Island in Lake Winnipeg, discovered by Mr. Tyrrell. Many of the groves on the head-waters of the Abittibi river lie at some distance from one another, but all these are included within the general northern limit. Sir John Richardson mentions an outlier of this species at Lac la Loche on the upper waters of the Churchill river, but subsequent observation has shown it to be a grove of Banksian pines.

4. White Cedar:- The outliers on the east side of the Bay of Fundy and on the west end of Prince Edward Island have been already referred to, as well as the remarkable one of Cedar Lake at the mouth of the Saskatchewan. Along the general boundary of this tree isolated groves occur in favourable situations, such as on limestone rocks and around the shores of lakes, where the warm season is prolonged by the slow escape of the heat which has been stored up in the water.

5. Hemlock Spruce.-A colony is said to exist near Thompson, in Minnesota, a short distance west of the head of Lake Superior; but the tree does not occur on the Kaministiquia river, Thunder Bay, as supposed by Sir John Richardson.

6. Balsam Poplar:-Several small patches occur on the headwaters of the Boll river, within the great area from which it is otherwise absent.

7. Basswood.-There is an outlier of this tree at Lake St. John, north of Quebec, and nearly one hundred miles beyond the general limit of the species.

8. Becch.-A small colony of this species occurs about two miles north of the town of Massey on Spanish river; but it is only a few miles outside of the main boundary. The beecil does not occur on the Red river of the North, as erroncously mentioned by Sir John Richardson, nor in the treeless region of Back's Great Fish river, as inaccurately stated by Dr. Sutherland.

9. Buttonuood. - A number of these trees were growing a few years ago along the Sageen river in the county of Bruce, far oittside of the main boundary.

The occurrence of outliers of so many species tends to disprove the theory that these phenomena are evidences of the dying out of a species on account of the antiquity of its origin. They are rather to be regarded as the precursors of the advance of the boundaries of the several species, the general tendency being towards enlargement.

\section{VACANT SPACHS.}

Blanks, or spaces within the general area of distribution of any tree in which no specimen of it can be found, are more liable to be overlooked 
than are outliers of any species, since the latter attract the attention of observers so much more easily. Mention has already been made of the immense inlying blank of the balsam poplar, which stretcles from the interior of Labrador to the Ottawa valley. There is a large area between James Bay and Lake Superior from which both the elm and black ash are absent, although this space is within the general range of both these species. This blank is probably owing to the greater elevation of the area, which in this latitude must have a considerable effect on the climate, rendering it less favourable than that of the belt of lower ground to the northward in which these two species are still sparingly scattered. The balsam fir is wanting in some tracts on the upper branches of the Albany river, in which it might be expected to be found.

It is believed that closer investigation may prove the existence of many vacant spaces within the general linits of various species, in which none of their representatives can be found, besides such areas as swamps, sand plains, etc., which are manifestly unsuited to their growth.

\section{Conditions Governing Distribution.}

In the part of Canada under consideration, the presence or absence of different trees, or the contours of the lines bounding their geographical distribution, are determined by general climatic conditions, modified to a greater or less degree by the following circumstances, which will be briefly considered :-

1. Distance or proximity of the sea, or of the areas which were covered by it in recent geological times.

2. Changes which have taken place in the arrangement of land and water while the trees were spreading over the continent.

3. General dryness or moisture of the climate affecting considerable areas.

4. Extremes of heat and cold.

5. Local heat and moisture from lakes and rivers.

6. General elevation above the sea.

7. Local elevations (with consequent dryness) over level, wet, or cold lands.

S. Large local depressions.

9. Diseases and insect pests.

10. Rapid or slow natural means of dispersion.

1. The opposite effects of the sea on the distribution of the Banksian pine and the balsam poplar have been already described. In the Labrador peninsula the tree-lines bend southward in approaching the coast on either side, showing that the sea has an unfavourable influence. The blighting effect of the cold Atlantic especially is very marked, as it prevents the growth of almost all timber on the coast-line, except the most hardy kinds in the southern part. The tree-lines run almost parallel to the ocean, the tenderer species being found farther and farther inland. Some linds of trees are found in the western part of Newfoundland which do not cross to the east side of the island in the

dista

white

birch

prairi

the $\mathrm{n}$

is an

mark

prove

date,

extent

may 1

accom

with :

where

the pr

circula region 
same latitudes. In New Brunswick and Nova Scotia the tree-lines all curve sonthwari, as if to avoid the influence of the cold water of the Gulf of St. Lawrence.

2. The effect of a different arrangement of land and water at a late geological period is seen principally in the absence of the white cedar from Nova Scotia, and its distance inland on the west side of James Bay. The course of the Banksian pine line round James Bay and north of the St. Lawrence has been caused by a former extension of the sea.

3. The greater dryness of the region between Red river and the Rocky mountains is one of the principal causes of its treeless and partially treeless condition. The former country is called plain, and the latter prairie. The other principal cause is the extremes of heat and cold. Some persons have jumped to the conclusion that the plains and prairies have resulted from repeated fires burning off pre-existing forests in modern times. If this were the case, the tree-lines in their general westward course would all end abruptly at the edge of the burnt space, and some traces of the various species would still be found in the prairie region. But, instead of this, on approaching the prairie country they all curve gradually to the southward in a concentric fashion, so that what was the northern limit of each successive species now becomes in turn its western boundary. Some species reach the Red river valley before they bend south, while others begin their curve at greater and greater distances off. Those affected in this way are the white cedar, black ash, white ash, white pine, red pine, sugar maple, red or soft maple, yellow birch, red oak, hemlock, ironwood, beech, and red cedar. Towards the prairie region these are replaced to some extent by western trees, such as the negundo or Manitoba maple, the green ash, and the cottonwood, which is another indication of climatic change in this region. Such wellmarked features of long-established forest distribution are sufficient to prove that the present divisions of prairie and woodland are of ancient date, and not due to the destruction of timber corresponding with the extent of the open country. But if other evidence be required, it may be found in the prairie flora, the absence of hollows, with hillocks accompanying them, left by the bodily upturning of the roots of trees with a large quantity of earth attached, which are always to be found where forests have grown; the comparative scarcity of water-courses, and the prevalence of regular rings of boulders around the edges of the nearly circular ponds which have resulted from the action of ice in a treeless region.

4. Extremes of heat and cold have also contributed to prevent the growth of the above-mentioned trees in the plain and prairie country.

We have already seen that some of our most southern trees may be successfully transplanted far beyond their present natural range; but the experiments which have been made in the plain and prairie regions seem to show that there only the hardiest trees will flourish at all. If the various species of the forest region lying to the enstward of the prairie region had recently flourished in the now open country, we should expect to find that they would grow again when planted there; but such is not the case. 
5. Local heat and moisture derived from lakes and rivers are beneficial to the growth of our northern trees, and in many localities they even determine the presence of some species. The white spruce, balsam poplar, etc. attain a greater size on the islands and along the banks of the large rivers flowing northward than at a distance from their influence. Along the North Saskatchewan, which flows through a dry region, the negundo, green ash, grey elm, white birch, and black alder grow only on the banks of the river. Everywhere in the white cedar region, as we approach its northern limit, these trees are confined to a border along the rivers and around the lakes. The most northerly outposts of the black ash occur at rapids in north-flowing streams, where the overhanging trees can enjoy the heat escaping from the water. In such advanced situations the tender leaves and shoots are apt to be nipped by the late spring frosts. Fruit is grown with more success on the southern sides of the larger lakes than elsewhere, as the air which moves from the northward off the water prevents the occurrence of summer frosts.

6. The effect of general elevation above the sea is well illustrated in the large area between James Bay and Lake Superior, in which no elm or black ash occur, whereas these trees grow to a good size on the Albany and the branches of Moose river to the northward.

7. Local elevation, and consequent dryness and warmth, as compared with adjacent low and cold lands, account for the growth of such trees as the sugar maple, ironwood, basswood, hemlock, etc. in many places north of the Ottawa and elsewhere at considerable distances beyond their last appearances in the river valleys. For the same reason, thrifty forests of yellow birch cover the hills in large districts north of Lake Huron.

8. Local depressions have a favourable influence in carrying the treelines northward. Lake Temiscaming, at the great bend of the Ottawa, lies in a north and south valley several hundred feet below the level of the surrounding. plateau, and here the white oak grows fully fifty miles beyond its general range, while the limits of several other species protrude some distance up the valley. Lake St. John, about 150 miles north of Quebec, is only slightly elevated above the sea-level, and the forest around it has a more southern character than that of the neighbouring high lands; but this may be partly due to the occurrence of nearly horizontal Silurian rocks. The basswood grows here apparently as an outlier, and the lines of the red oak, sugar maple, yellow bircli, and red pine curve northward so as to include the lake.

9. Diseases and insect pests have occasionally some effect on forest growth in Canada. A few years ago most of the spruce-trees over a large tract in New Brunswick and the Gaspé peninsula died of a disease which was accompanied by a white fungus upon the roots. About the year 1889 an imported saw-fly commenced to attack the larches in the region to the south-east of James Bay, and, being in a uew country without natural enemies, it spread with wonderful rapidity. By the year 1895 it had killed most of the larch-trees all the way from Rupert's House to within 100 miles of Ottawa city, and from these points to the centre of the Labrador peninsula, a distance of some 500 miles each way. 


\section{Tree-Lines in Minnesota.}

The State of Minnesota is situated in a very interesting region in regard to forest distribution. Here we find the northern limit of the group of trees to which the most southern species of Ontario belong, such as the black walnut, buttonwood, shell-bark hickory, hackberry, and Kentucky coffee-tree; the north-western limit of the commoner trees of the northern States and of Quebec and Ontario, such as the white oak, red cedar, ironwood, white ash, rock elm, red oak, yellow birch, sugar maple, red maple, etc.; the western boundaries of some of the trees whose northern limits pass through northern Ontario, such as the white cedar, black ash, white pine, and red pine; the southern limits of the most northern group, including the white and black spruce, the larch, Banksian pine, balsam fir, balsam poplar, and canoe birch; and the general eastern limits of some of the western species, such as the negundo or Manitoba maple, the green ash, and the cottonwood. The boundaries of the trees of Minnesota have been mapped out by Professor N. H. Winchell, State geologist.

\section{The Great Northern Forest.}

Reference has already been made to the great northern forest of Canada, which stretches from the Strait of Belle Isle round by the southern end of James Bay to Alaska, a distance of about 4000 miles, with a breadth of some 700 miles. This vast forest has everywhere the same characteristic features. The trees, as a rule, are not large, and they consist essentially of the following nine species :-black spruce, white spruce, Banksian pine, larch, balsam fir, aspen, balsam poplar, canoe birch, and bird cherry, with several kinds of small willows, which, however, seldom attain the size of trees. White cedar, white and red pine, black ash, and rowan occur sparingly in the southern part of this belt.

\section{Frres and Second Growth.}

As a rule, any extensive view over this vast region presents a "patchy" appearance, owing to the different shades of green covering larger or smaller areas. These various shades indicate growths of different ages, which commenced after forest fires at different periods; but ultimately the trees all go through the same stages, and arrive at maturity in the same number of years. These patches may be of limited extent, or they may embrace many thousands of square miles, but a uniform process is going on in each of them. It begins with the complete destruction by fire of the preëxisting growth of trees, and ends with a burning of the newly matured forest similar to that which preceded it.

\section{Forest Fires are Natural Phenomena.}

These fires are natural phenomena, being mostly due to lightning in the summer-time, and they have no doubt been going on from time immemorial. Lightning is of frequent occurrence during the hot, dry season 
in all parts of Canada. At this time of the year we read in the newspapers of numerous buildings being set on fire every week from this cause, and we should naturally expect many fires to originate in the same way in the forests, and there is ample proof that they do originate in this manner, especially in these northern woods. The writer has been an eyewitness to the fact, and most persons who have travelled much in theso regions have seen the same thing happen. A description of one of these great fires in our northern forest-belt forms a part of their natural history, being the concluding event from which the growth starts afresh.

\section{Fires in the Northlirs Fonest.}

Let us imagine ourselves in an old forest of this region, of practically unlimited extent, and consisting of a dense growth of black and white spruce, Banksian pino, tamarack, and balsam fir. The smaller trees fill up the spaces between the larger ones, and all are crowded so closely together that their branches touch or intermingle with each other. In this way a sufficiently dense mass of fuel is formed to support a continuous sheet of flame on a grand scale, and yet it is sufficiently open to furnish a plentiful supply of air to carry on the conflagration. The ground is deeply covered with moss, and an accumulation of fallen trees and branches is lying about in all directions. After the prolonged hot weather and drought of the summer months the moisture has become thoroughly dried out of the gummy boughs of the standing trees, leaving their great store of resin and turpentine, as well as the wood itself, all ready for burning. The mossy carpet and the fallen timber are alike dry. All the conditions are now ready, and only await a spark of fire to start one of the wildest and grandest scenes of destruction which can take place on the face of the earth.

When the fire has got under way the pitchy trees burn with almost explosive rapidity. The flames rush through their branches and high above their tops with a terrifying sound. The ascending heat soon develops a strong breeze, if a wind does not happen to be blowing already. Before this gale the fire sweeps on with a roaring noise as fast as a horse can gallop. The irresistible front of flame devours the forest before it as rapidly as a prairie fire licks up the dry grass. The line of the gigantic cenflagration has a height of 100 feet or more above the tree-tops, or 200 feet from the ground. Great sheets of flame disconnect themselves from the fiery avalanche and leap upward as towering tongues of fire, or dart forward, bridging over wide spaces, such as lakes and rivers, and starting the fire afresh in advance of the main column, as if impatient of the slower progress it is making. These inmense shooting flames aro probably due to the large quantities of highly inflammable gas evolved by the heat from the pitchy tree-tops just in advance of actual combustion, and they help to account for the incredible speed of most of the larger forest fires.

One of them, which occurred in the Saguenay region, and of which we have exact particulars, was known to run over 150 miles in ten hours, or at the rate of fifteen miles an hour. Thus in a single day the appear-

ance 11 or mol have $\mathrm{b}$ fires, 1 about than a north in the of $\mathrm{mil}$ stroyir of tim north: from $t$

$\mathrm{Th}$ ing no flagrat flee fo animal of the they $n$ which confus the he fall int change extent chain

Th after $t$ blacker plants, trees w trees. years, They presen and be covered By this branch growth the mo years sharp lighter 
anco which a large tract of country is to wear for the next hundred years or more is completely changed. Even greater tracts of country than this have bceu known to be burnt up at a single conflagration. One of these fires, which started west of Lake Superior and swept round its north side about 1845, was ascertained to have travelled about 300 miles in less than a week. A few years later another fire extended from the country north of Lake Huron into the Ottawa valley, a distance of some 200 miles, in the space of a few days. Three or four years ago, forest fires, hundreds of miles long, swept through Michigan, Wisconsin, and Minnesota, destroying several hundreds of human lives, and millions of dollars' worth of timber. Some of the great fires of the almost boundless forests farther north seem to have been even more extensivo, from all that we can learn from the natives in regard to them.

The wild animals appear to understand the significance of the roaring noise and the clouds of smoke in the sky in advance of these conflagrations. The terrified deer, bears, wolves, foxes, lynxes, and hares flee for their lives, followed by multitudes of the small fur-bearing animals; but as a rule all aro soon overtaken and destroyed. Should any of the larger beasts be fortunate enough to reach a lake or river in time, they may escape along with the beavers, muskrats, otters, and minks, which seldom stray far from the water. The birds fly up into the air in confusion in advance of the wall of fire, and appear to become stifled by the heat and smoke, and after fluttering about for a few minutes thoy fall into the flames and perish.

These great fires come to an end in different ways. It may be by a change in the wind, followed by a deluge of rain, or by coming to a wide extent of previously burnt country, or of small deciduous trees, or to a chain of large lakes.

\section{Evolution of the New Forests.}

The dead trunks of the larger trees generally stand for many years after the fire. In the summer following one of these conflagrations, the blackened ground becomes partly covered by a growth of herbaceous plants, berry bushes, and shoots from the roots and butts of deciduous trees which have retained some vitality, besides numerous small seedling trees. The huckleberry bushes, which are very common for the first few years, especially on rocky, siliceous ground, bear abundant crops of fruit. They have sprung from large old roots which are almost everywhere present in the thick woods, although their tops are quite inconspicuous, and bear few or no berries. In fifteen or twenty years the ground is covered with poplars, birches, willows, etc., to a height of about thirty feet. By this time the dead trunks of the old brule have lost most of their branches, and the smaller ones have fallen down. If we look under this growth, we shall discover many healthy young conifers overshadowed by the more rapidly growing deciduous trees. At the end of about fifty years the conifers are everywhere showing their heads, in the form of sharp apices, their dark green colour contrasting strongly with the lighter shades of the other trees. In the race to get above the deciduous 
growth, they develop tall trunks with the branches high up. In one hundred years the poplars are dying and falling down, and the canco birch has attained maturity and soon after shows signs of old age. Meantime the older conifers have overtopped the other trees and given a new character to the general appearance of the forest. The younger conifers of various ages, which have been springing up from seed every year, take possession of the ground left by the decay of the first occupants, and in about one hundred and fifty years the forest has again become almost entirely coniferous, and is re ady to be destroyed once more by fire. Such is the rotation of crops of trees which is perpetually going on in these regions. Perhaps one-third of the whole area consists of "second growths" of less than fifty years, one-third of trees from fifty to one hundred years old, while the remaining third may be one hundred years and upwards.

\section{The Banksian Pine in relation to Fire}

Fire appears to be a necessity in the propagation of the Banksian pine. Its knotty cones are not deciduous, but stick to the tree as long as it lasts, the older crops becoming covered with lichens and showing great age. If the tree dies or falls over and decays, the cones lie about unopened. But when the standing trees are scorched by a forest fire, the cones immediately open, and the seeds become scattered far and wide by the wind. Forest fires have probably occurred every year since trees of the present species existed on the continent, and an interesting question arises as to how the Banksian pine acquired this curious habit. Charred woed occurs under great depths of Pleistocene deposits near Toronto, while there is no evidence of the advent of man in Canada until a very recent period. 


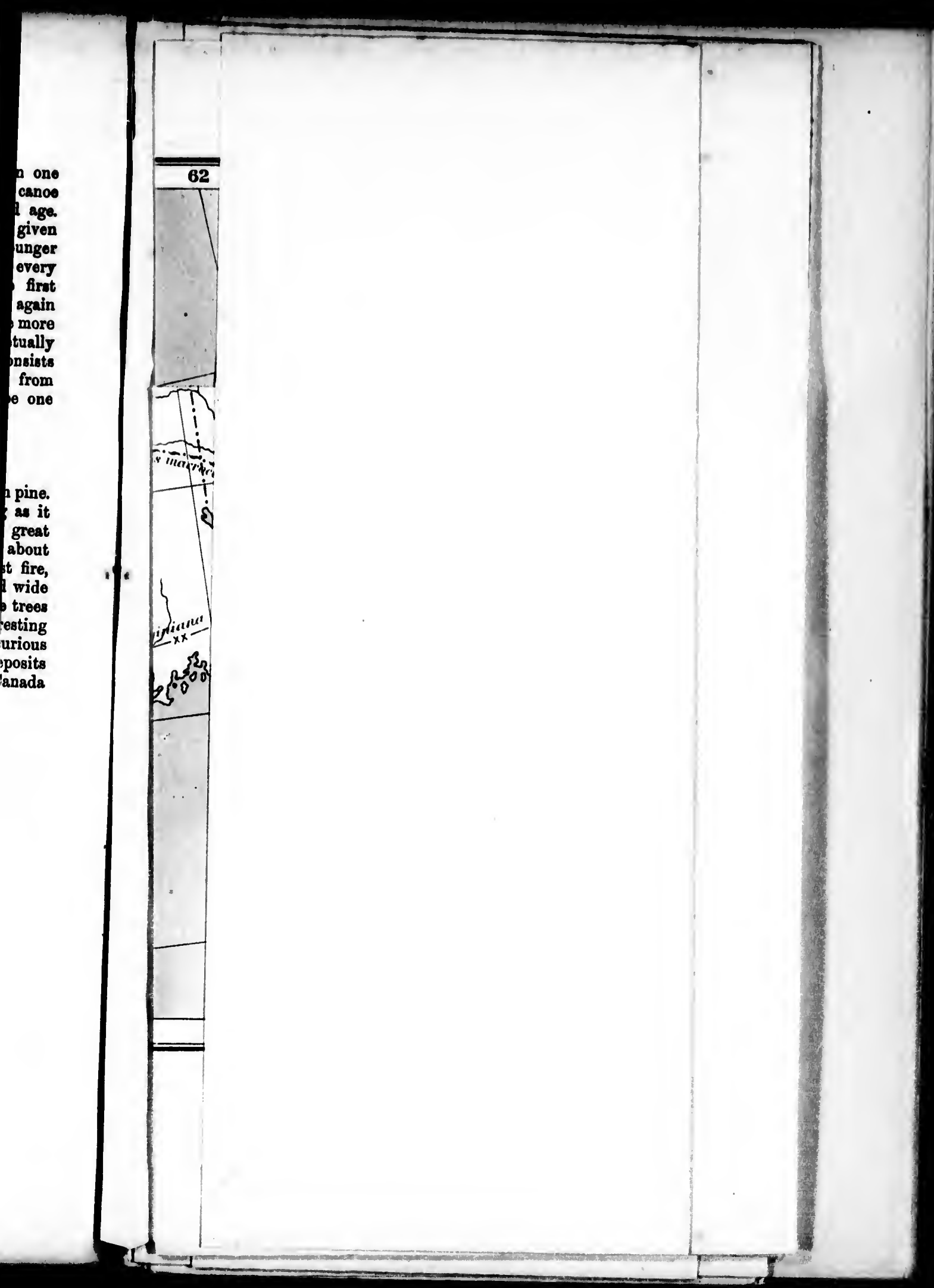




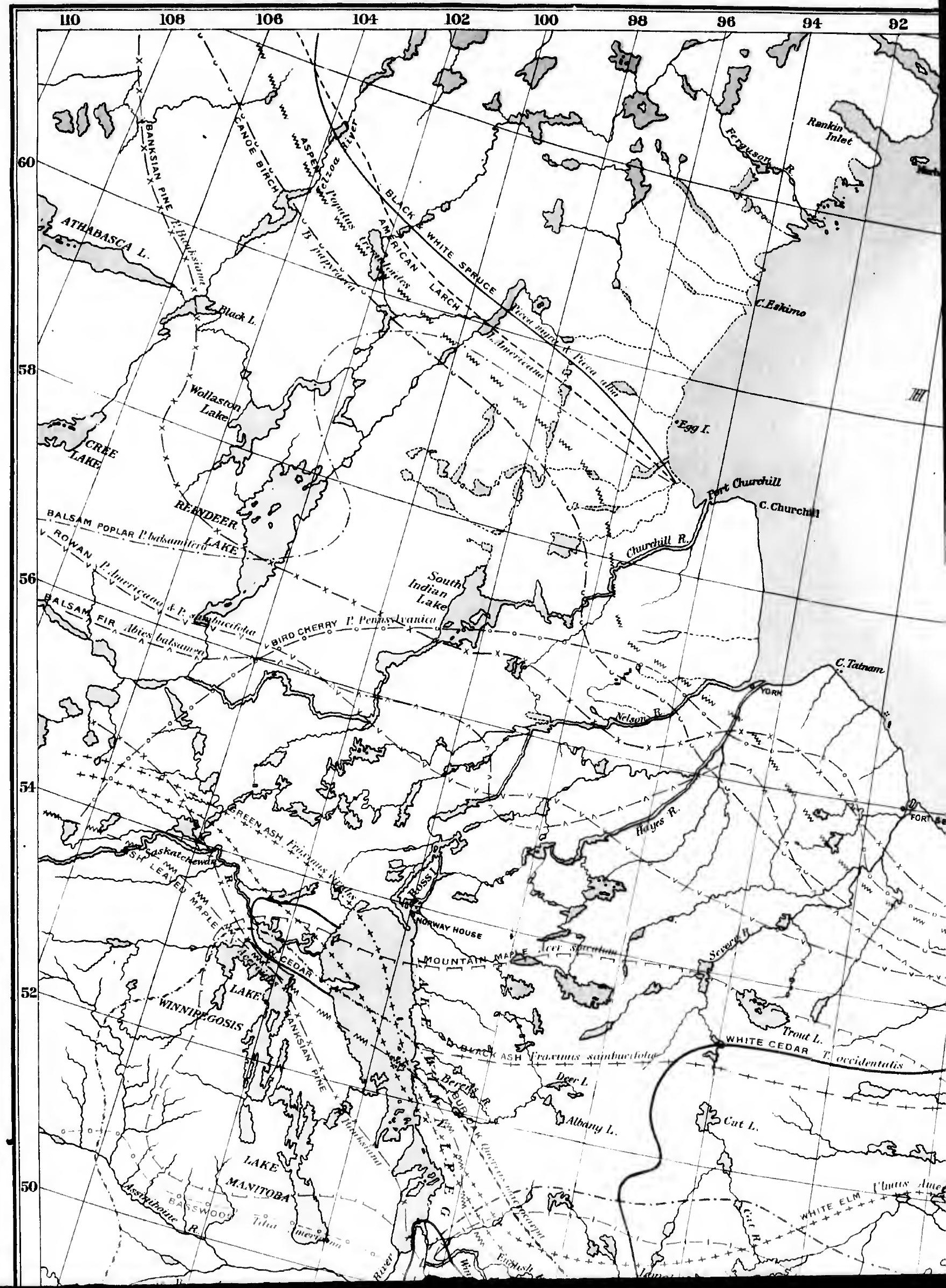




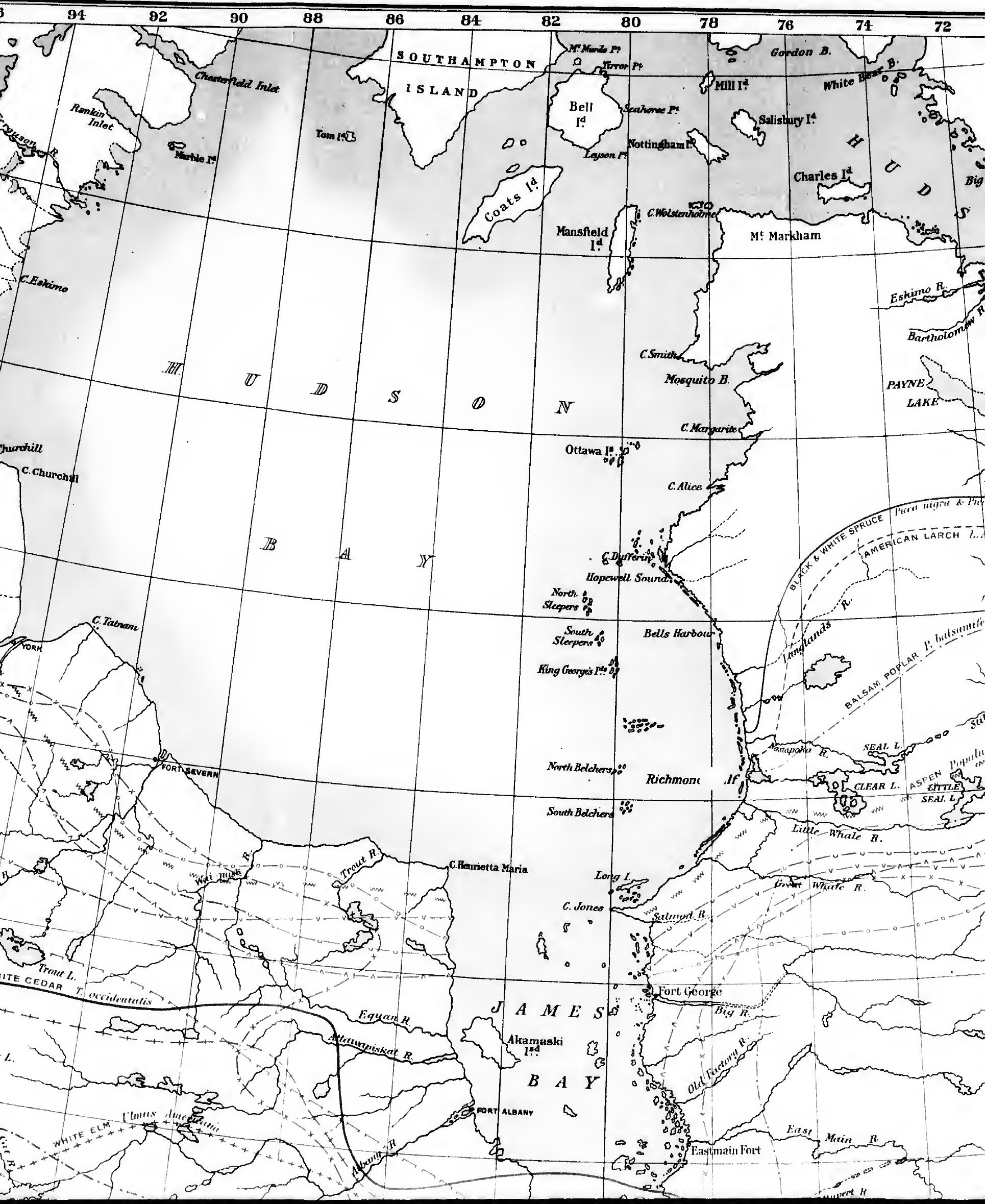




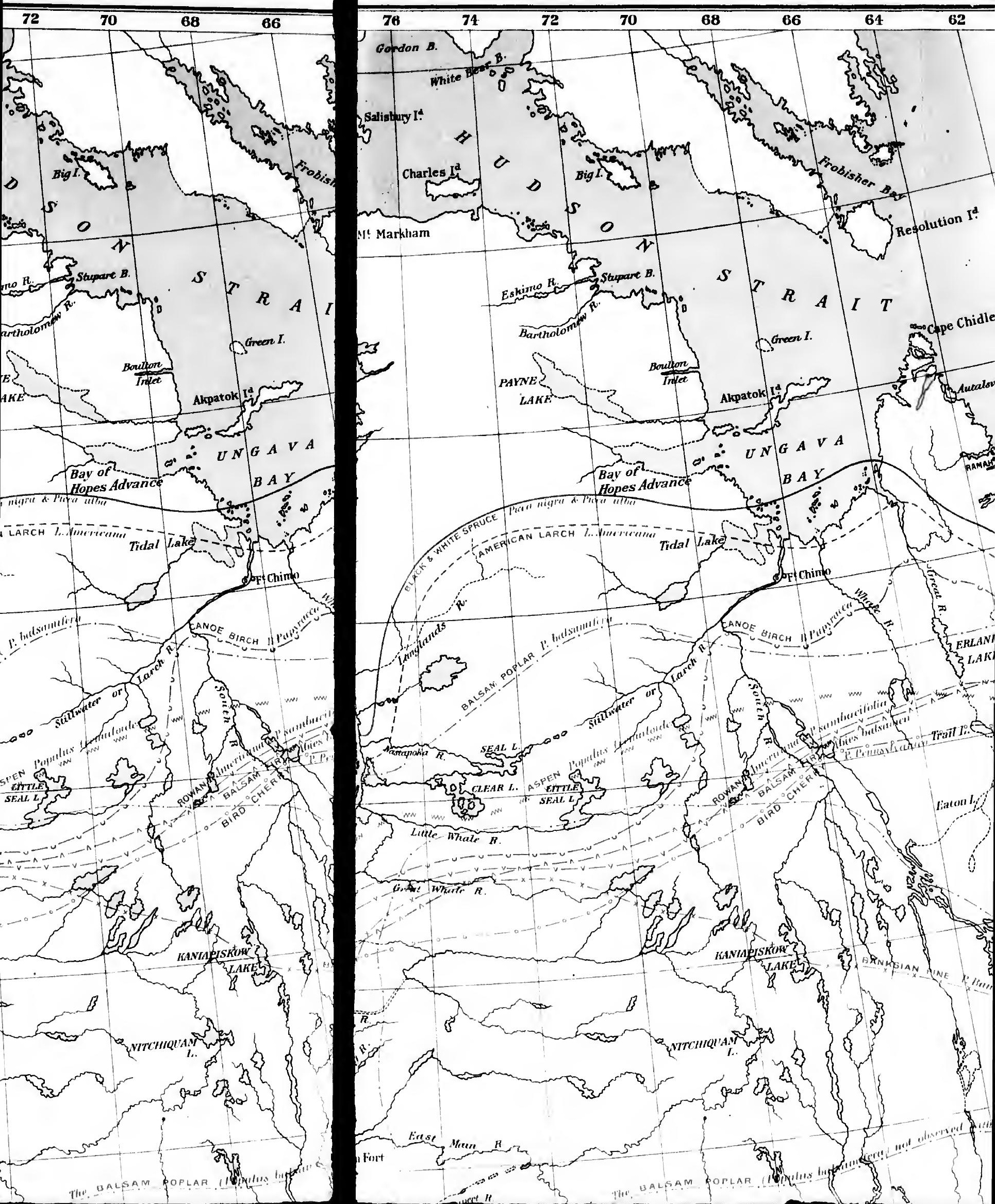




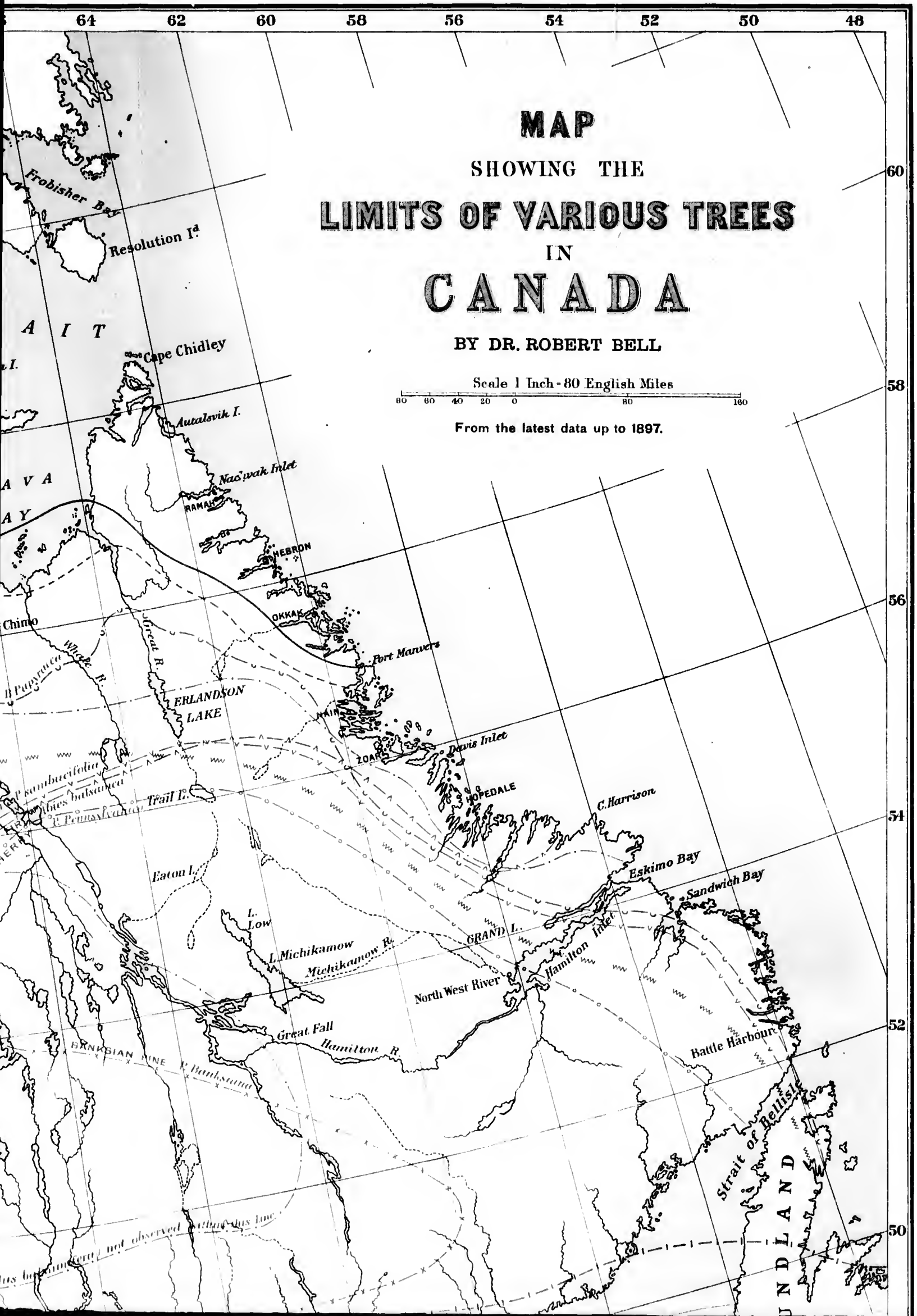




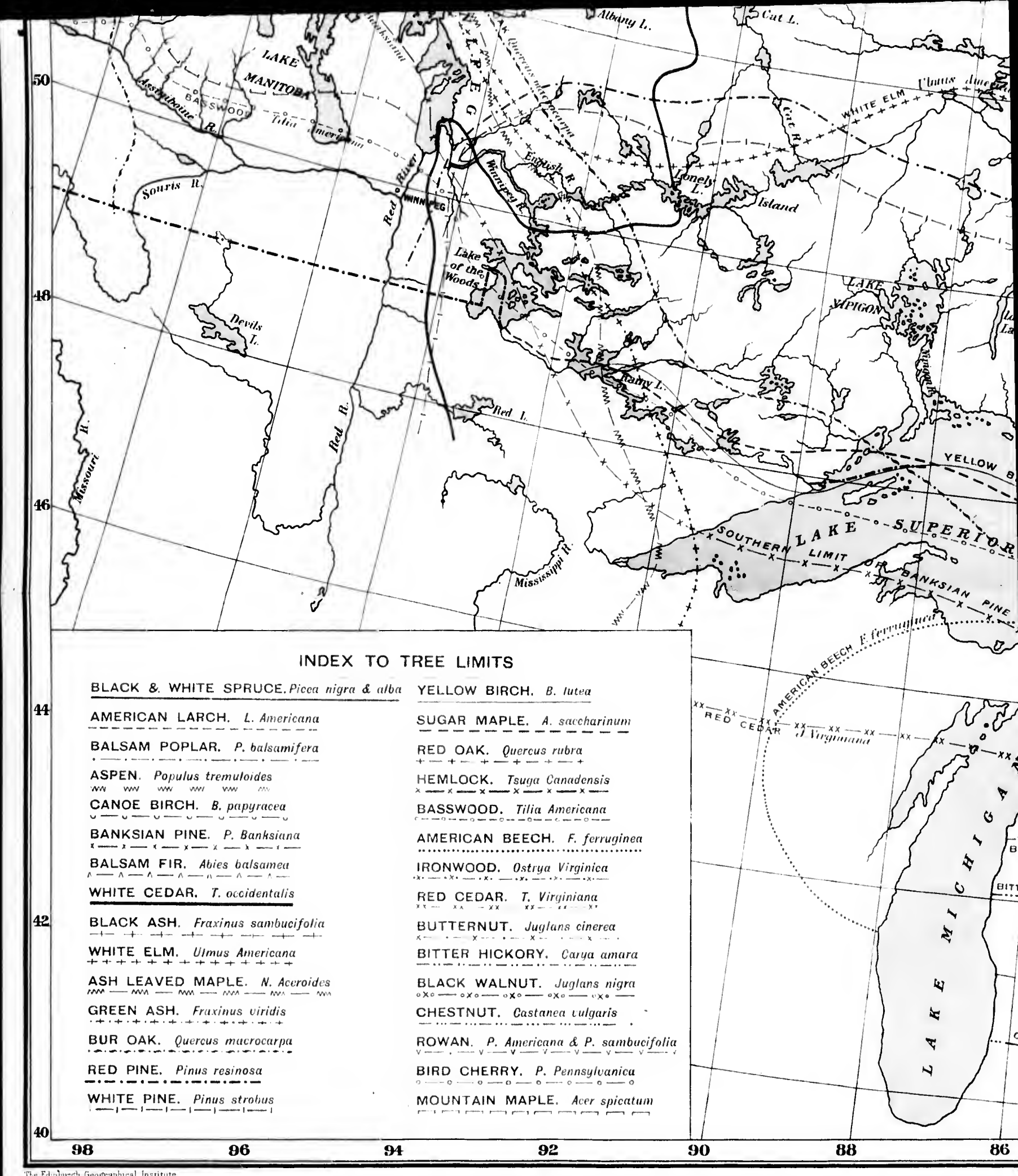




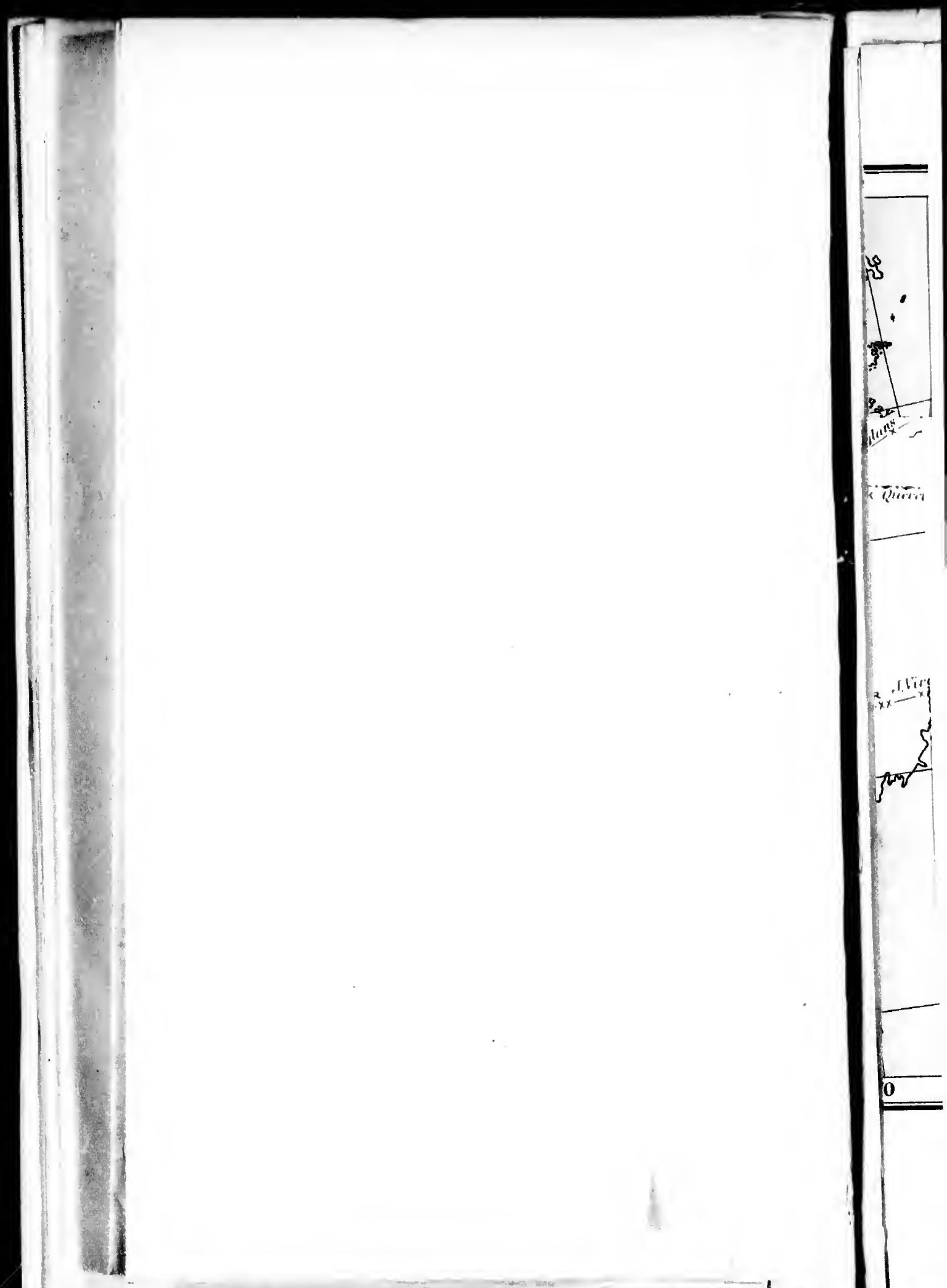



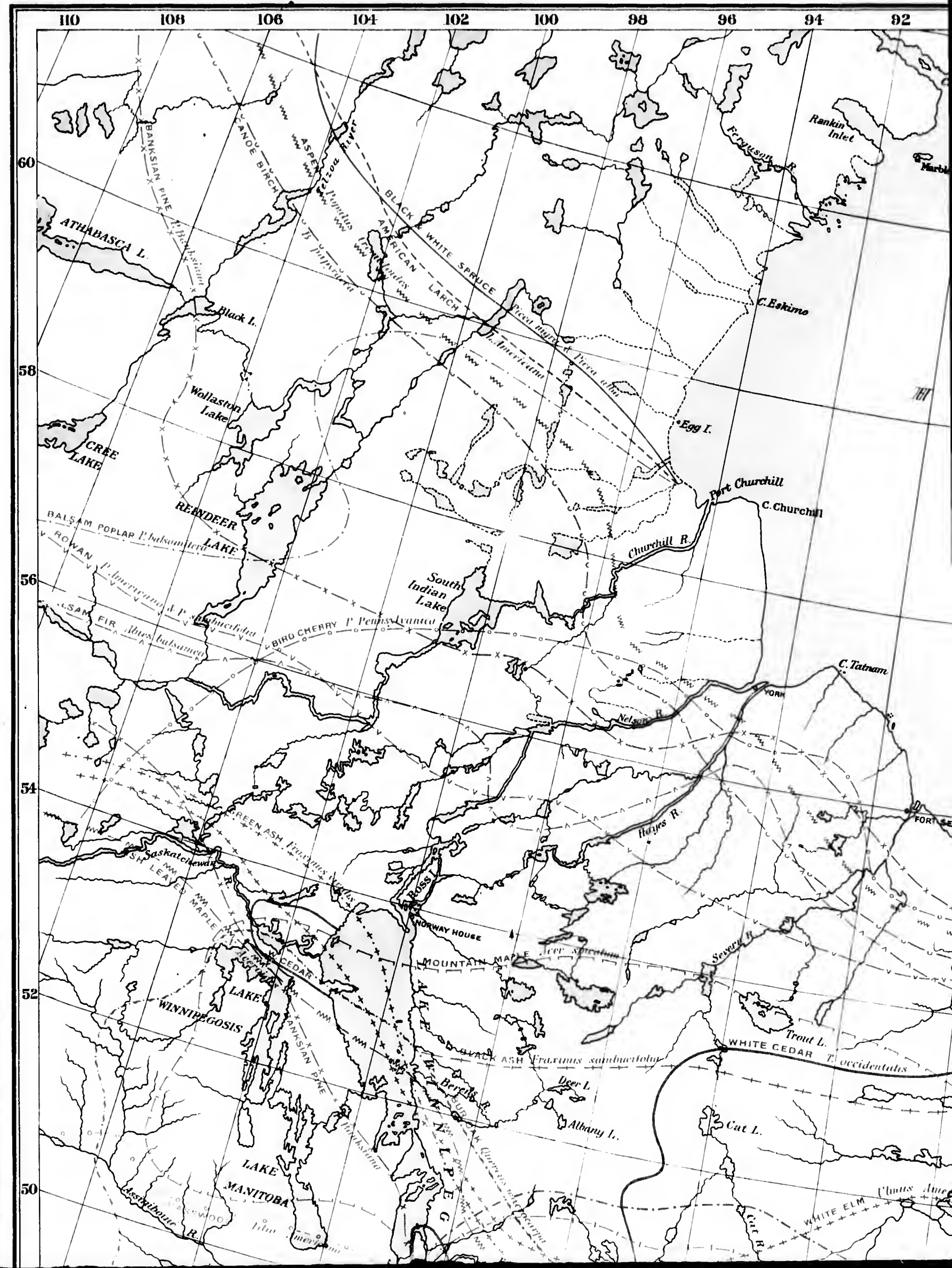




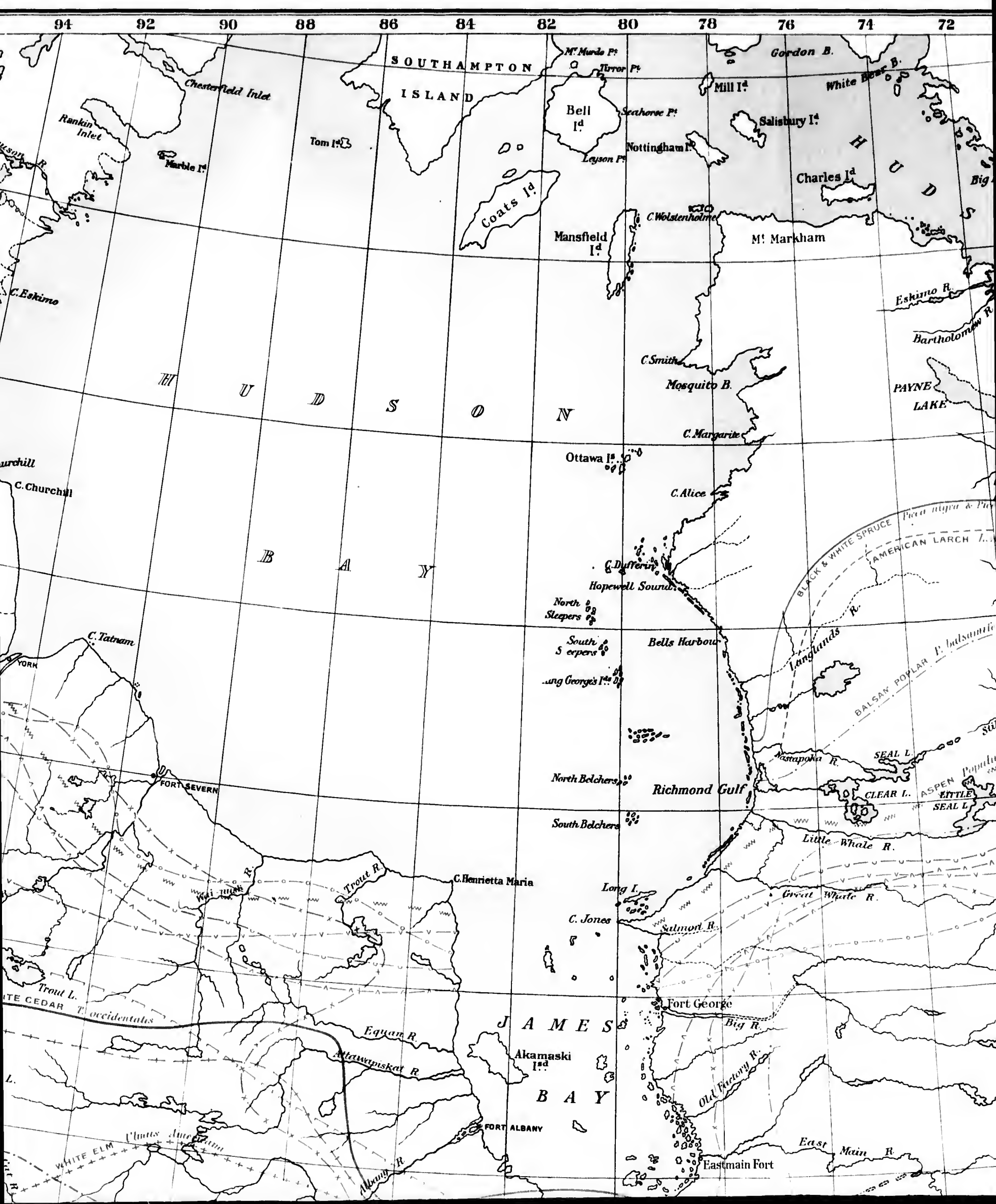




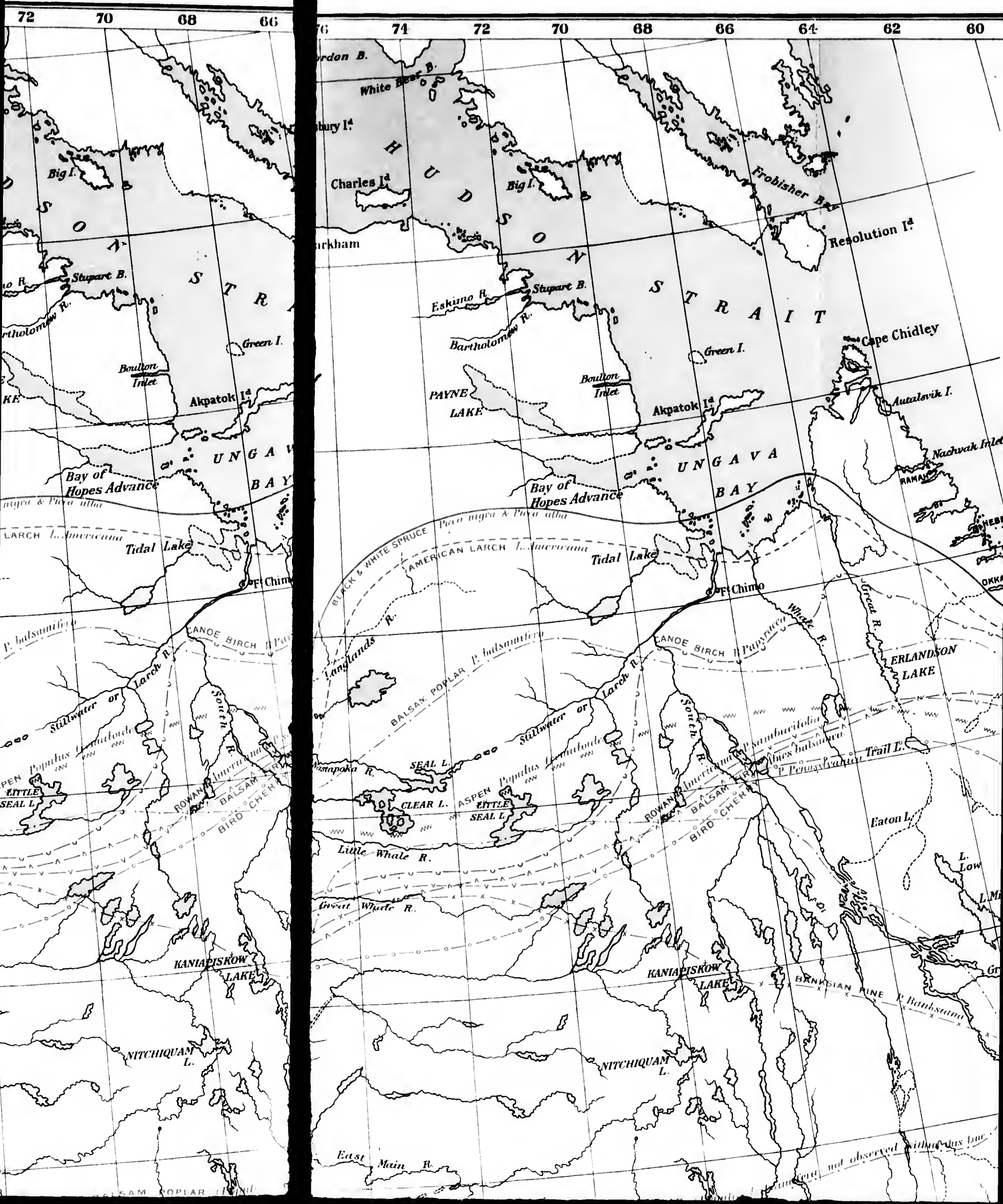




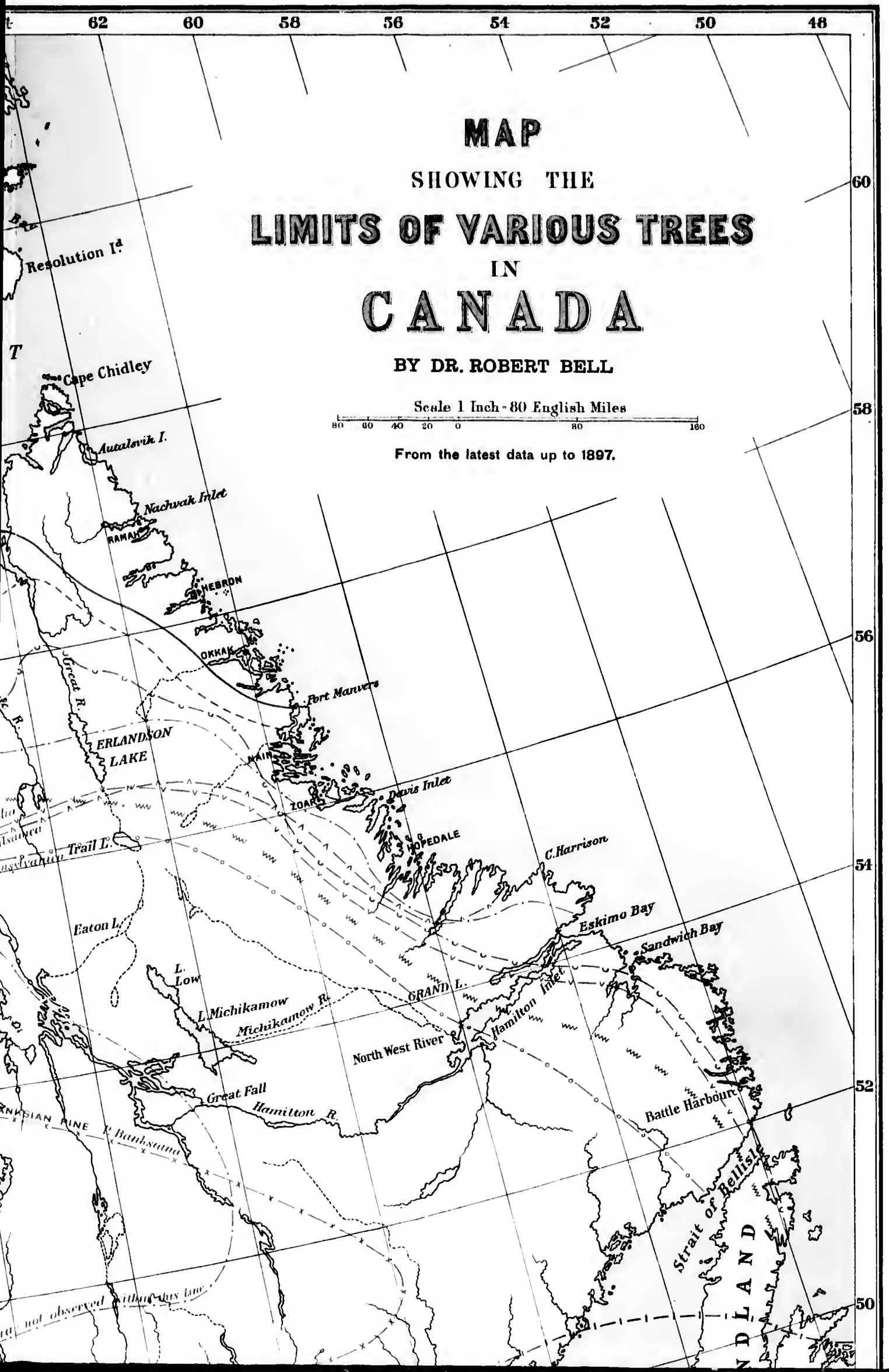




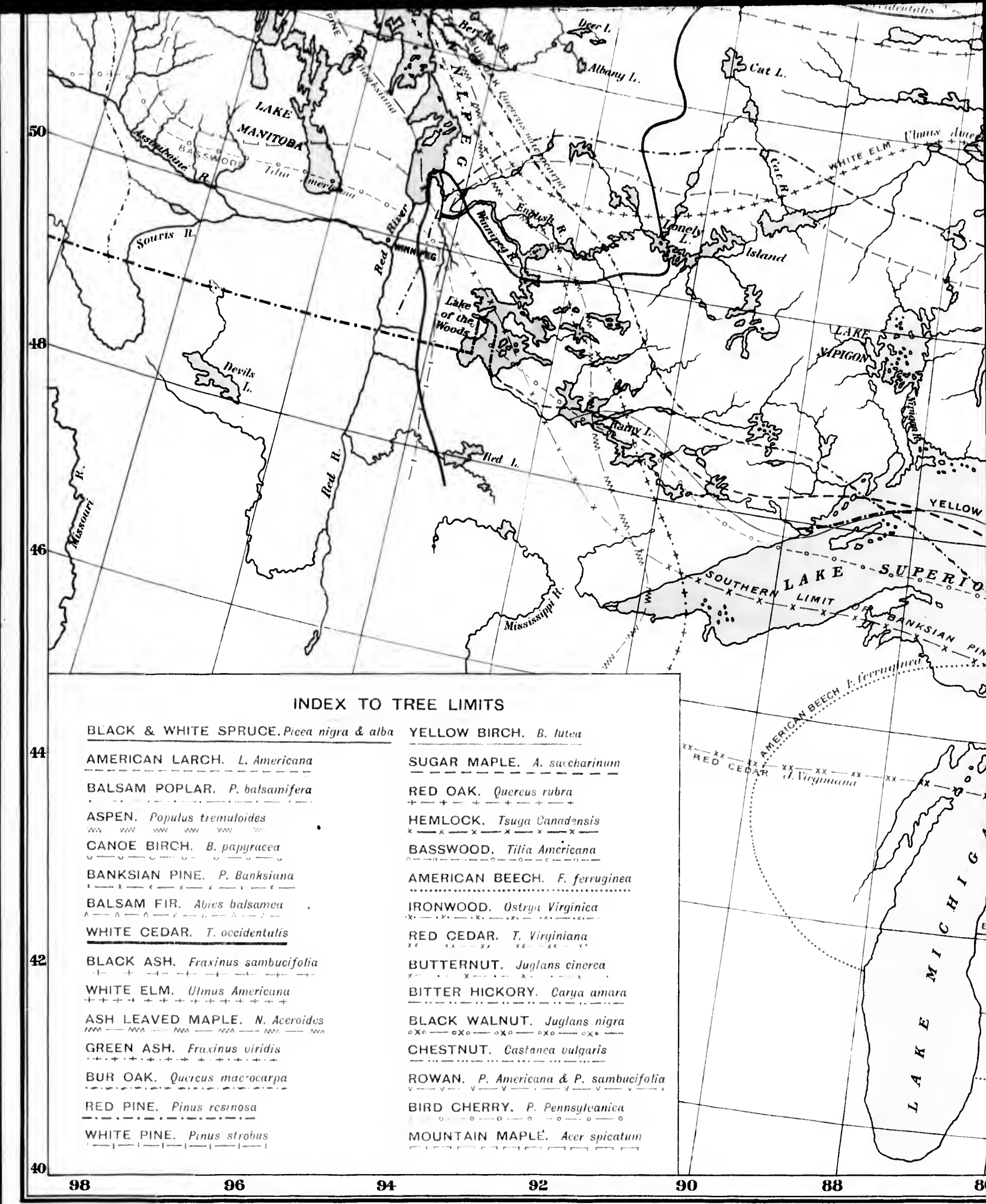


Cond

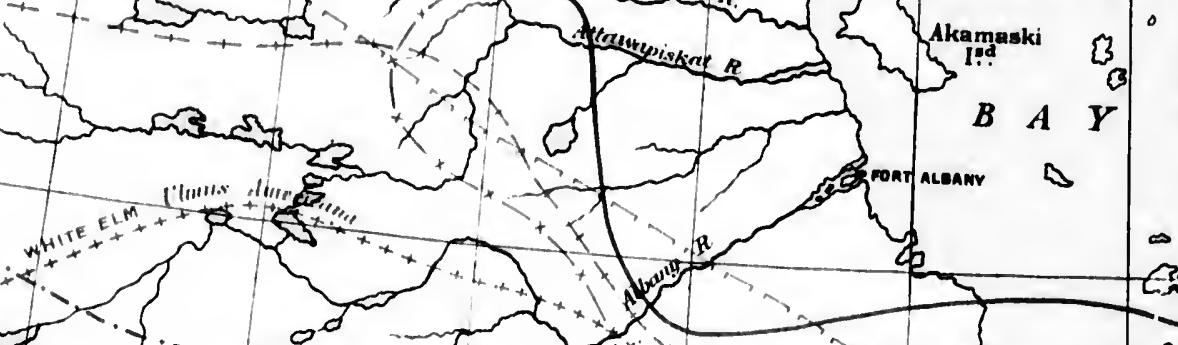

$\rightarrow 005$

$\infty \quad 0 \%$ Eastmain Fort

Erese Main Rin

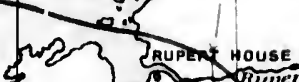
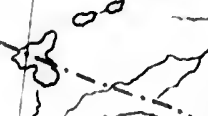

(c)

(c)

(c)

in 3

(n)

5 CS

$1-\frac{100}{20} 25$

Gome

$1 \mathrm{~K} \mathrm{E}$

are

,

of Bivartios

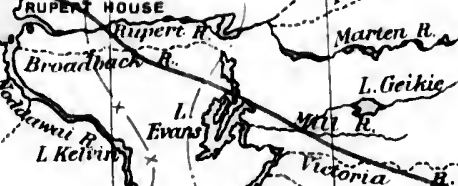




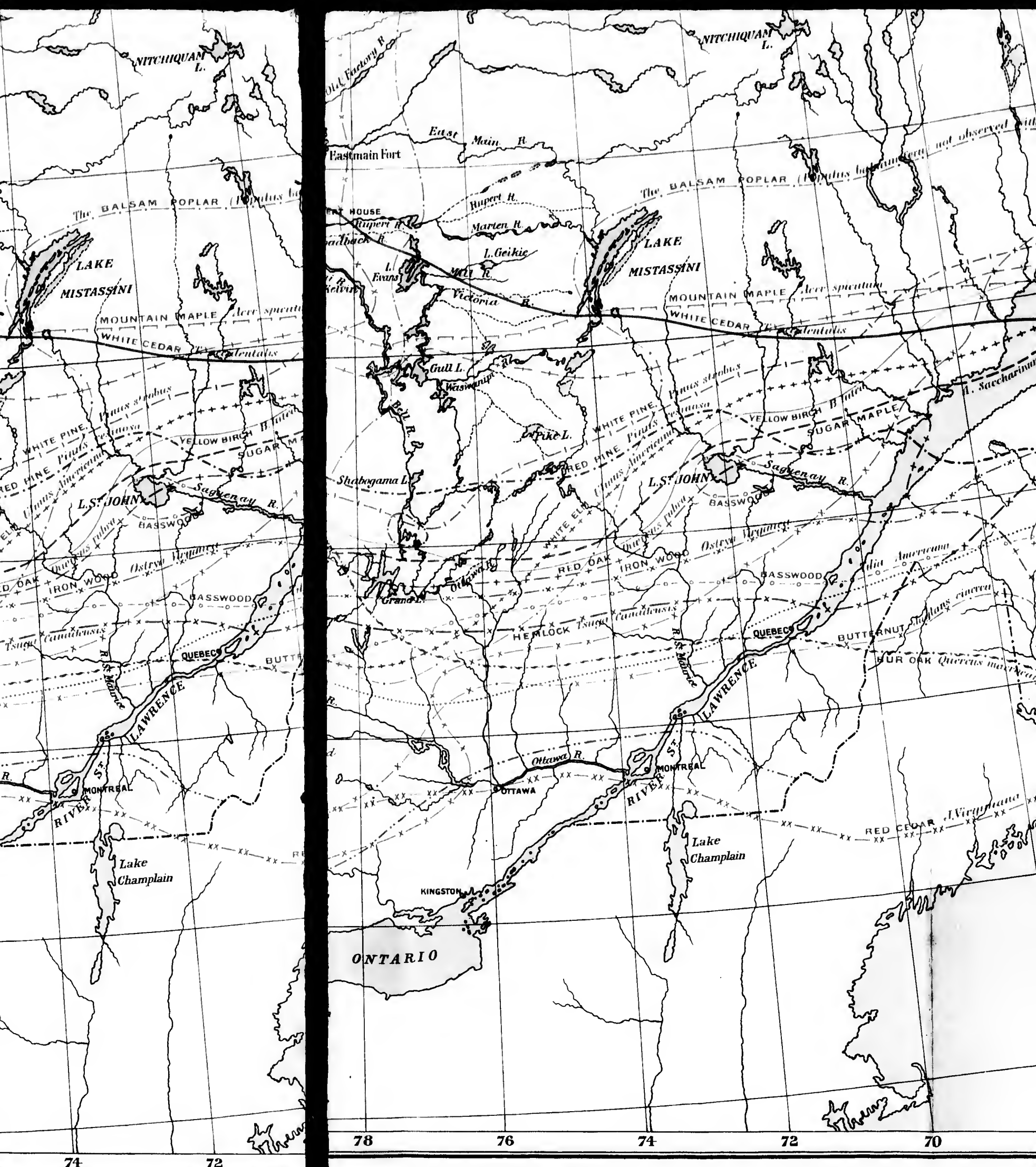




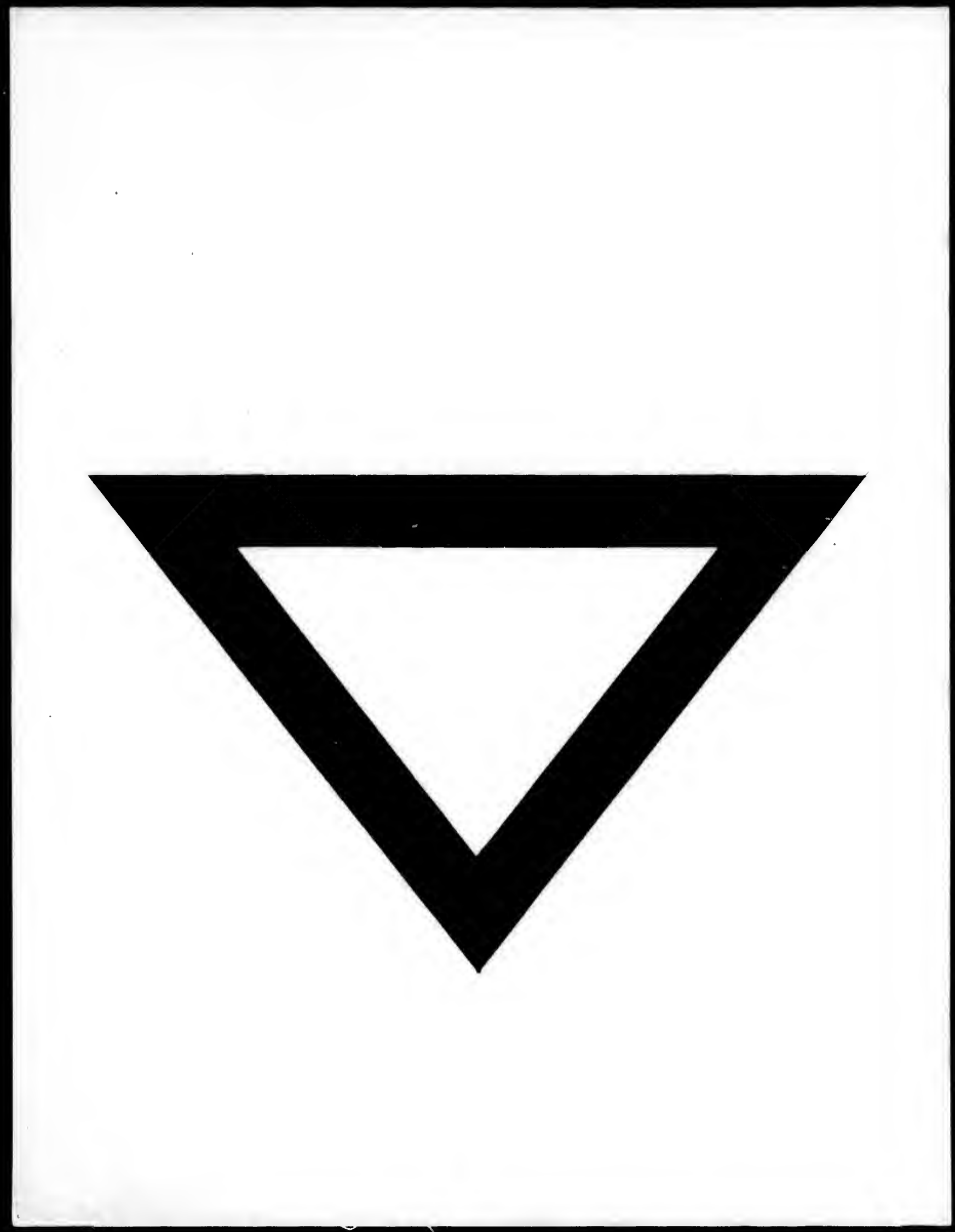

